\title{
Hydrogen Sulfide Alleviates Postharvest Senescence of Grape by Modulating the Antioxidant Defenses
}

\author{
Zhi-Jing Ni, ${ }^{1,2}$ Kang-Di Hu, ${ }^{1}$ Chang-Bing Song, ${ }^{2}$ Run-Hui Ma, ${ }^{1,2}$ Zhi-Rong Li, ${ }^{1}$ \\ Ji-Lian Zheng, ${ }^{1}$ Liu-Hui Fu, ${ }^{1}$ Zhao-Jun Wei, ${ }^{1}$ and Hua Zhang ${ }^{1}$ \\ ${ }^{1}$ School of Food Science and Engineering, Hefei University of Technology, Hefei 230009, China \\ ${ }^{2}$ Biological Science and Engineering College, Beifang University of Nationalities, Yinchuan 750021, China \\ Correspondence should be addressed to Zhao-Jun Wei; zjwei@hfut.edu.cn and Hua Zhang; hzhanglab@hfut.edu.cn
}

Received 4 April 2016; Accepted 26 June 2016

Academic Editor: Guangdong Yang

Copyright (C) 2016 Zhi-Jing Ni et al. This is an open access article distributed under the Creative Commons Attribution License, which permits unrestricted use, distribution, and reproduction in any medium, provided the original work is properly cited.

Hydrogen sulfide $\left(\mathrm{H}_{2} \mathrm{~S}\right)$ has been identified as an important gaseous signal in plants. Here, we investigated the mechanism of $\mathrm{H}_{2} \mathrm{~S}$ in alleviating postharvest senescence and rotting of Kyoho grape. Exogenous application of $\mathrm{H}_{2} \mathrm{~S}$ released from $1.0 \mathrm{mM}$ NaHS remarkably decreased the rotting and threshing rate of grape berries. $\mathrm{H}_{2} \mathrm{~S}$ application also prevented the weight loss in grape clusters and inhibited the decreases in firmness, soluble solids, and titratable acidity in grape pulp during postharvest storage. The data of chlorophyll and carotenoid content suggested the role of $\mathrm{H}_{2} \mathrm{~S}$ in preventing chlorophyll breakdown and carotenoid accumulation in both grape rachis and pulp. In comparison to water control, exogenous $\mathrm{H}_{2} \mathrm{~S}$ application maintained significantly higher levels of ascorbic acid and flavonoid and total phenolics and reducing sugar and soluble protein in grape pulp. Meanwhile, $\mathrm{H}_{2} \mathrm{~S}$ significantly reduced the accumulation of malondialdehyde (MDA), hydrogen peroxide $\left(\mathrm{H}_{2} \mathrm{O}_{2}\right)$, and superoxide anion $\left(\mathrm{O}_{2}{ }^{-{ }^{-}}\right)$in grape pulp. Further investigations showed that $\mathrm{H}_{2} \mathrm{~S}$ enhanced the activities of antioxidant enzymes ascorbate peroxidase (APX) and catalase (CAT) and decreased those of lipoxygenase (LOX) in both grape peels and pulp. In all, we provided strong evidence that $\mathrm{H}_{2} \mathrm{~S}$ effectively alleviated postharvest senescence and rotting of Kyoho grape by modulating antioxidant enzymes and attenuating lipid peroxidation.

\section{Introduction}

Grapes are subject to postharvest senescence during storage, in the syndromes of serious water loss, berry softening, offflavour occurrence, and decay caused mainly by Botrytis cinerea, which reduces the commodity and consumption of grapes [1]. Besides, rachis browning is also an important storage problem of grapes, which greatly affects consumer preference and fruit price [2]. The universal practice to control postharvest decay is to fumigate grapes with $\mathrm{SO}_{2}$. Despite the obvious effect of $\mathrm{SO}_{2}$ in controlling fungal spreading and postharvest rotting, $\mathrm{SO}_{2}$ treatment causes tissue damage to grape berry such as cracks and bleaching and also leads to excessive sulfite residue which may induce allergenic effects $[3,4]$. Thus, developing novel technologies to prolong the shelf life of grapes is of great importance to both grape growers and consumers.
Hydrogen sulfide $\left(\mathrm{H}_{2} \mathrm{~S}\right)$ has been identified as a third multifunctional endogenous gaseous signal after nitric oxide (NO) and carbon monoxide (CO) in animal system [5]. In plants, $\mathrm{H}_{2} \mathrm{~S}$ emission has been found in many plant species such as cucumber, squash, pumpkin, soya bean, and cotton $[6,7]$. More recently, the metabolism and function of endogenous $\mathrm{H}_{2} \mathrm{~S}$ have been clarified through $\mathrm{H}_{2} \mathrm{~S}$-generation defect mutants, revealing its role in plant growth and development [8-10]. Accumulating evidence indicates that $\mathrm{H}_{2} \mathrm{~S}$ functions in various processes in plants, including seed germination, root organogenesis, abiotic stress tolerance, photosynthesis, guard cell movement, and postharvest senescence, suggesting that $\mathrm{H}_{2} \mathrm{~S}$ acts as an important signaling molecule in plants, as do $\mathrm{NO}$ and $\mathrm{CO}$ [11-17].

Fruit senescence is usually accompanied by physiological and biochemical changes among which oxidative damage 
caused by reactive oxygen species (ROS) such as $\mathrm{O}_{2}{ }^{--}$and $\mathrm{H}_{2} \mathrm{O}_{2}$ are universally observed [18]. Several recent studies found that $\mathrm{H}_{2} \mathrm{~S}$ could attenuate oxidative stress by modulating antioxidant enzymes in some postharvest fruits and vegetables including strawberry, mulberry, kiwifruit, and broccoli [19-22]. However, there is no study on whether $\mathrm{H}_{2} \mathrm{~S}$ plays a role in delaying the senescence of postharvest grape. In the present research, $\mathrm{H}_{2} \mathrm{~S}$ donor sodium hydrosulfide (NaHS) solution was applied to fumigate grapes and the effects of $\mathrm{H}_{2} \mathrm{~S}$ signal on grape senescence, the metabolism of natural antioxidants, and ROS and on the activities of antioxidant enzymes were investigated.

\section{Materials and Methods}

2.1. Plant Material and Treatments. Clusters of fresh Kyoho grape (Vitis vinifera L. $\times$ V. labrusca L. cv. Kyoho) were kindly supplied by the orchard of Anhui Academy of Agricultural Sciences, Anhui, China, and grape samples of commercial ripeness, similar bunch size, and no disease and injury were used in this study. Solution of sodium hydrosulfide (NaHS. $3 \mathrm{H}_{2} \mathrm{O}$, Sigma) was used as $\mathrm{H}_{2} \mathrm{~S}$ donor. Aqueous solutions of NaHS at different concentrations $(150 \mathrm{~mL})$ of $0,0.20,0.40,0.60,0.80,1.00,1.20,1.40,1.60,1.80,2.00$, or $2.20 \mathrm{mM}$ were prepared in sealed containers (volume $3 \mathrm{~L}$ ) and the solutions were renewed daily. Twelve groups of grape clusters in three replicates (approx. $150 \mathrm{~g}$ per replicate) were fumigated with $\mathrm{H}_{2} \mathrm{~S}$ in the sealed containers at $25^{\circ} \mathrm{C}$ and a relative humidity of $85-90 \%$. Grape clusters exposed to $\mathrm{H}_{2} \mathrm{~S}$ fumigation were photographed daily, and the rotten and threshing berries of three replicate grapes were recorded. Rotten fruit rate $(\%)=($ the number of rotten berries (berries with mildew or rot) + the number of threshing berries)/total number of berries in a replicate.

2.2. Quality Evaluation of Grapes. Grape clusters were fumigated with water or $\mathrm{H}_{2} \mathrm{~S}$ released from $1.0 \mathrm{mM} \mathrm{NaHS}$ in the sealed containers at $25^{\circ} \mathrm{C}$ and a relative humidity of $85-90 \%$ for 7 days and relative data were analyzed. Browning index of grape rachis was evaluated according to the browning scales as follows: 0 , no browning; 1 , browning scale less than a quarter of total area of rachis; 2, browning of scales less than $1 / 2$ of total area of rachis; 3 , browning of scales less than threequarters of total area of rachis; and 4, more than 3/4 of total area of rachis. Browning index (BI) was calculated daily by the following formula: $\mathrm{BI}=\sum(d f) / N D$, where $d$ is the browning of scales on the grape rachis and $f$ is its respective quantity; $N$ is the total number of grape rachis examined; and $D$ is the highest browning of scales.

For weight loss percentage, the weight of grape clusters was measured before treatment $(a)$ and after storage $(b)$. The weight loss was calculated as $(a-b) / a$.

Grape firmness was measured at the equatorial part of individual grape by a 5-mm diameter flat probe with a texture analyzer (Model TA XT plus, SMS). The penetration depth was $5 \mathrm{~mm}$ and the crosshead speed was $5 \mathrm{~mm} \cdot \mathrm{s}^{-1}$. Fruit firmness values were an average of 8 grape berries \pm SD (standard deviation).
The total soluble solids (TSS) were determined by measuring the refractive index of the fruit with a hand refractometer (Tongfang Inc., Shanghai, China) according to the method of Jiang et al. [23]. The values were an average of 10 replicates of grapes \pm SD.

The titratable acidity of the grape (pooled juice of 15 berries, three replicates per treatment) was measured by titration with $0.1 \mathrm{mM} \mathrm{NaOH}$ to $\mathrm{pH}$ 8.3. The results were expressed as $\mathrm{g} \cdot \mathrm{L}^{-1}[24]$.

\subsection{Determination of Chlorophyll and Carotenoid Contents} in Grape Rachis and Pulp. Chlorophyll content of grape was determined using the colorimetric method according to Lichtenthaler and Wellburn [25] with minor modifications. About $5.0 \pm 0.05 \mathrm{~g}$ of finely chopped grape flesh samples or $2.5 \pm 0.02 \mathrm{~g}$ of finely chopped grape rachis samples was homogenized using a pestle and mortar on ice and incubated in an Erlenmeyer flask containing $10 \mathrm{~mL}$ of $80 \%$ acetone as extraction solvent. After extraction in darkness for $24 \mathrm{~h}$ at $4^{\circ} \mathrm{C}$, the supernatant was measured at 663 and $645 \mathrm{~nm}$, respectively. Chlorophyll and carotenoid contents were calculated with the following equations: Carotenoid $=A_{440} V / W$; Chla $=\left(12.7 A_{663}-2.69 A_{645}\right) \mathrm{V} / \mathrm{W} ;$ Chlb $=\left(22.9 A_{663}-\right.$ $\left.4.68 A_{645}\right) V / W$; and Chl = Chla + Chlb. Chlorophyll and carotenoid contents were expressed as $\mathrm{mg} \cdot \mathrm{g}^{-1} \mathrm{FW}$.

2.4. Determination of Ascorbic Acid, Flavonoid, Total Phenolics, Reducing Sugar, and Soluble Protein in Grape Pulp. Ascorbic acid was determined by the method described by Nath et al. [26]. Grape pulp samples $5.0 \pm 0.05 \mathrm{~g}$ were ground with $15 \mathrm{~mL}$ of $4 \%$ oxalic acid. After centrifugation at $5,000 \mathrm{rpm}$ for $15 \mathrm{~min}$ at $4^{\circ} \mathrm{C}$, the supernatant was adjusted to $25 \mathrm{~mL}$ with $2 \%$ oxalic acid and titrated with 2,6dichlorophenol-indophenol to a pink color.

Determination of total phenolics and flavonoid in grape pulp was performed according to the methods of Pirie and Mullins [27] and Zhishen et al. [28], respectively.

Soluble protein and reducing sugar contents in grape pulp were measured according to Bradford [29] and Miller [30], respectively. Grape pulp samples at $5.0 \pm 0.05 \mathrm{~g}$ were ground with $3 \mathrm{~mL}$ of sodium phosphate buffer ( $\mathrm{pH} 7.0$, $200 \mathrm{mM}$ ), and the homogenate was centrifuged at 10,000 rpm for $30 \mathrm{~min}$ at $4^{\circ} \mathrm{C}$. Then, the supernatant was collected for the determination of soluble protein and reducing sugar content. For soluble protein, $0.1 \mathrm{~mL}$ of supernatant was mixed with $0.9 \mathrm{~mL}$ of $\mathrm{dH}_{2} \mathrm{O}$ and $5 \mathrm{~mL}$ of Coomassie Brilliant Blue. Absorbance was recorded at $595 \mathrm{~nm}$ after $5 \mathrm{~min}$. The results were expressed as $\mu \mathrm{g} \cdot \mathrm{g}^{-1} \mathrm{FW}$.

Reducing sugar was measured by the dinitrosalicylic acid method. The supernatant $(0.2 \mathrm{~mL})$ was mixed with $1.5 \mathrm{~mL}$ of 3,5-dinitrosalicylic acid and $1.8 \mathrm{~mL}$ of $\mathrm{dH}_{2} \mathrm{O}$, and then the mixture was heated at $100^{\circ} \mathrm{C}$ for $5 \mathrm{~min}$, cooled, and added to $25 \mathrm{~mL}$ distilled water. Reducing sugar was determined at $540 \mathrm{~nm}$ by a spectrophotometer, and the results were expressed as $\mathrm{mg} \cdot \mathrm{g}^{-1} \mathrm{FW}$.

2.5. Determination of Malondialdehyde (MDA), Hydrogen Peroxide $\left(\mathrm{H}_{2} \mathrm{O}_{2}\right)$, and Superoxide Anion $\left(\mathrm{O}_{2}{ }^{--}\right)$in Grape Pulp. Contents of MDA and $\mathrm{H}_{2} \mathrm{O}_{2}$ and generation of $\mathrm{O}_{2}{ }^{\cdot-}$ were 
determined according to the methods described by $\mathrm{Hu}$ et al. [22] with minor modifications. For MDA analysis, grape pulp samples $(5.00 \pm 0.05 \mathrm{~g})$ were ground in liquid nitrogen and extracted in $3 \mathrm{~mL} 0.1 \%$ trichloroacetic acid (TCA). The homogenate was centrifuged at $12,000 \mathrm{rpm}$ for $20 \mathrm{~min}$ and $1.8 \mathrm{~mL}$ of the supernatant fraction was mixed with $1.8 \mathrm{~mL}$ of $20 \%$ TCA containing $0.5 \%$ thiobarbituric acid. The mixture was incubated at $100^{\circ} \mathrm{C}$ for $30 \mathrm{~min}$, cooled, and centrifuged at $12,000 \mathrm{rpm}$ for $10 \mathrm{~min}$. Absorbance was recorded at $532 \mathrm{~nm}$, and the value for nonspecific absorption at $600 \mathrm{~nm}$ was subtracted. An extinction coefficient of $155 \mathrm{mM}^{-1} \cdot \mathrm{cm}^{-1}$ was used to calculate MDA content which was expressed as $\mu \mathrm{mol} \cdot \mathrm{g}^{-1}$.

For determination of $\mathrm{H}_{2} \mathrm{O}_{2}$, grape pulp samples (5.00 \pm $0.05 \mathrm{~g}$ ) were ground and extracted in $3 \mathrm{~mL}$ cold acetone. The homogenate was centrifuged at $12,000 \mathrm{rpm}$ at $4^{\circ} \mathrm{C}$ for $30 \mathrm{~min}$ and $0.5 \mathrm{~mL}$ of the supernatant fraction was mixed with $1.5 \mathrm{~mL}$ of $\mathrm{CHCl}_{3}$ and $\mathrm{CCl}_{4}(1: 3, \mathrm{~V} / \mathrm{V})$ mixture. Subsequently, $2.5 \mathrm{~mL}$ of distilled water was added and the mixture centrifuged at $12,000 \mathrm{rpm}$ for $1 \mathrm{~min}$ and the aqueous phase collected for determination. The reaction system included $1 \mathrm{~mL}$ sample, $0.5 \mathrm{~mL}$ of buffer (phosphate-buffered saline, $200 \mathrm{mM}$, pH 7.8), and $20 \mu \mathrm{L}$ ( 0.5 unit) of catalase as control or inactive catalase protein (catalase inactivated by heating in boiling water for $5 \mathrm{~min}$ ). After the mixture was incubated at $37^{\circ} \mathrm{C}$ for $10 \mathrm{~min}$, $0.5 \mathrm{~mL}$ of $200 \mathrm{mM}$ titanium 4-(2-pyridylazo) resorcinol (TiPAR) was added. The reaction mixture was incubated at $45^{\circ} \mathrm{C}$ for another $20 \mathrm{~min}$. Absorbance at $508 \mathrm{~nm}$ was measured and $\mathrm{H}_{2} \mathrm{O}_{2}$ content was indicated as $\mu \mathrm{g} \cdot \mathrm{g}^{-1} \mathrm{FW}$.

The generation rate of $\mathrm{O}_{2}^{\cdot-}$ was determined using hydroxylamine method. Grape pulp samples $(5.00 \pm 0.05 \mathrm{~g})$ were ground with $3 \mathrm{~mL}$ of $50 \mathrm{mM}$ Tris- $\mathrm{HCl}$ buffer $(\mathrm{pH}$ 7.8) and the homogenate was centrifuged at $12,000 \mathrm{rpm}$ at $4^{\circ} \mathrm{C}$ for $30 \mathrm{~min}$. The reaction mixture $(0.5 \mathrm{~mL})$ contained $50 \mathrm{mM}$ Tris- $\mathrm{HCl}$ buffer (pH 7.5), $0.5 \mathrm{mM}$ XTT [sodium, 3-1(phenylamino-carbonyl)-3, 4-tetrazolium-bis(4-methoxy-6nitro), and benzenesulfonic acid hydrate], and $50 \mu \mathrm{L}$ of sample extracts. Corrections were made for the background absorbance in the presence of $50 \mathrm{U}$ of superoxide dismutase (SOD).

\subsection{Activity Assays of APX, CAT, and LOX in Grape Peels and} Pulp. Activities of ascorbate peroxidase (APX, EC 1.11.1.11) and catalase (CAT, EC 1.11.1.6) were determined by the procedures described by García-Limones et al. [31]. Grape pulp samples $(5.00 \pm 0.05 \mathrm{~g})$ or grape peel samples $(2.0 \pm 0.02 \mathrm{~g})$ were homogenized with $5 \mathrm{~mL}$ of ice-cold sodium phosphate buffer ( $50 \mathrm{mM}, \mathrm{pH} 7.5$, containing $5 \mathrm{mM}$ beta mercaptoethanol and $1 \%$ polyvinyl pyrrolidone). The homogenate was centrifuged at $10,000 \mathrm{rpm}\left(4^{\circ} \mathrm{C}, 20 \mathrm{~min}\right)$, and the supernatant was used for activity measurement.

APX activity was determined by the decrease of ascorbate which was measured in absorbance at $290 \mathrm{~nm}$. The reaction mixture contained $2.5 \mathrm{~mL} 50 \mathrm{mM} \mathrm{K}$-phosphate buffer $(\mathrm{pH}$ 7.0), $0.2 \mathrm{~mL} 10 \mathrm{mM}$ ascorbic acid, $0.1 \mathrm{~mL} 3 \% \mathrm{H}_{2} \mathrm{O}_{2}$, and $0.2 \mathrm{~mL}$ crude enzyme extract.

CAT activity was determined spectrophotometrically by monitoring the decrease in absorbance at $240 \mathrm{~nm}$. The reaction mixture contained $2.8 \mathrm{~mL}$ of sodium phosphate buffer
(50 mM, pH 7.0), $100 \mu \mathrm{L}$ of $3 \% \mathrm{H}_{2} \mathrm{O}_{2}$, and $100 \mu \mathrm{L}$ enzyme extract.

Activity of LOX (EC 1.13.11.12) was detected by the procedure described by Surrey [32]. One unit of LOX was defined as a decrease of $0.01 \mathrm{OD}$ value in absorbance per minute. The results of APX, CAT, and LOX were expressed as $\mathrm{U} \cdot \mathrm{g}^{-1} \mathrm{FW}$.

2.7. Statistical Analysis. The data in the paper are based on three or more replicates in each experiment, and the experiments were repeated independently for three times and similar change pattern was observed. Statistical significance was tested by one-way analysis of variance (ANOVA) using IBM SPSS Statistics (SPSS version 20.0, Armonk, NY), and the results were expressed as the means $\pm \mathrm{SD}$. Least significant difference test was performed on all data following ANOVA tests to test for significant $(P<0.05$ or $P<0.01)$ differences between treatments.

\section{Results}

3.1. $\mathrm{H}_{2} \mathrm{~S}$ Alleviates Postharvest Senescence and Rotting of Kyoho Grape. Grape clusters were fumigated with $\mathrm{H}_{2} \mathrm{~S}$ released from aqueous solutions of NaHS ranging from $0.2 \mathrm{mM}$ to $2.2 \mathrm{mM}$ with water treatment as controls. The visual effects of $\mathrm{H}_{2} \mathrm{~S}$ on delaying grape senescence, berry cracking, rotting, and threshing are shown in Figure 1(a). As for control berries and $2.2 \mathrm{mM} \mathrm{NaHS}$ treated ones, rotten fruit rate increased steadily with storage time, whereas $1.0 \mathrm{mM} \mathrm{NaHS}$ could remarkably decrease the rotten and threshing rate of grape berries and was used for subsequent experiments (Figure 1(b)).

3.2. Effect of $\mathrm{H}_{2} \mathrm{~S}$ on the Browning Index of Grape Rachis, Weight Loss, Firmness, Total Soluble Solids, and Titratable Acidity of Berries. Rachis browning is a common problem that affects grape quality and consumer preference. As shown in the lower right part of Figure 1(a), grape rachis in $1.0 \mathrm{mM}$ $\mathrm{NaHS}$ treated grape clusters still retained a green appearance on day 5 of storage, while the control rachis developed serious browning. Also illustrated in Figure 2(a), browning index of water control rachis increased steadily to $100 \%$ on day 5 compared with $30 \%$ of NaHS treated ones.

Whole-cluster weight loss of $\mathrm{H}_{2} \mathrm{~S}$ treatment and water control is presented in Figure 2(b). The weight loss percentage of control grape clusters went up steadily to about 4.3 on day 8 of storage, while the weight loss was effectively alleviated in $\mathrm{H}_{2} \mathrm{~S}$ treatment. Berry firmness of water control declined gradually during storage, whereas only slight decrease in firmness was observed in berries treated with $\mathrm{H}_{2} \mathrm{~S}$ (Figure 2(c)).

As shown in Figure 2(d), the content of soluble solids of control grape berries decreased sharply along with storage. However, $\mathrm{H}_{2} \mathrm{~S}$ application maintained significantly higher levels of soluble solids compared with that of control except on day 2 of storage. Titratable acidity (Figure 2(e)) in control berries dropped sharply until day 4 and thereafter maintained a stable level, which is a symbol of an enhanced ripening. In contrast, titratable acidity in NaHS treatment showed a 

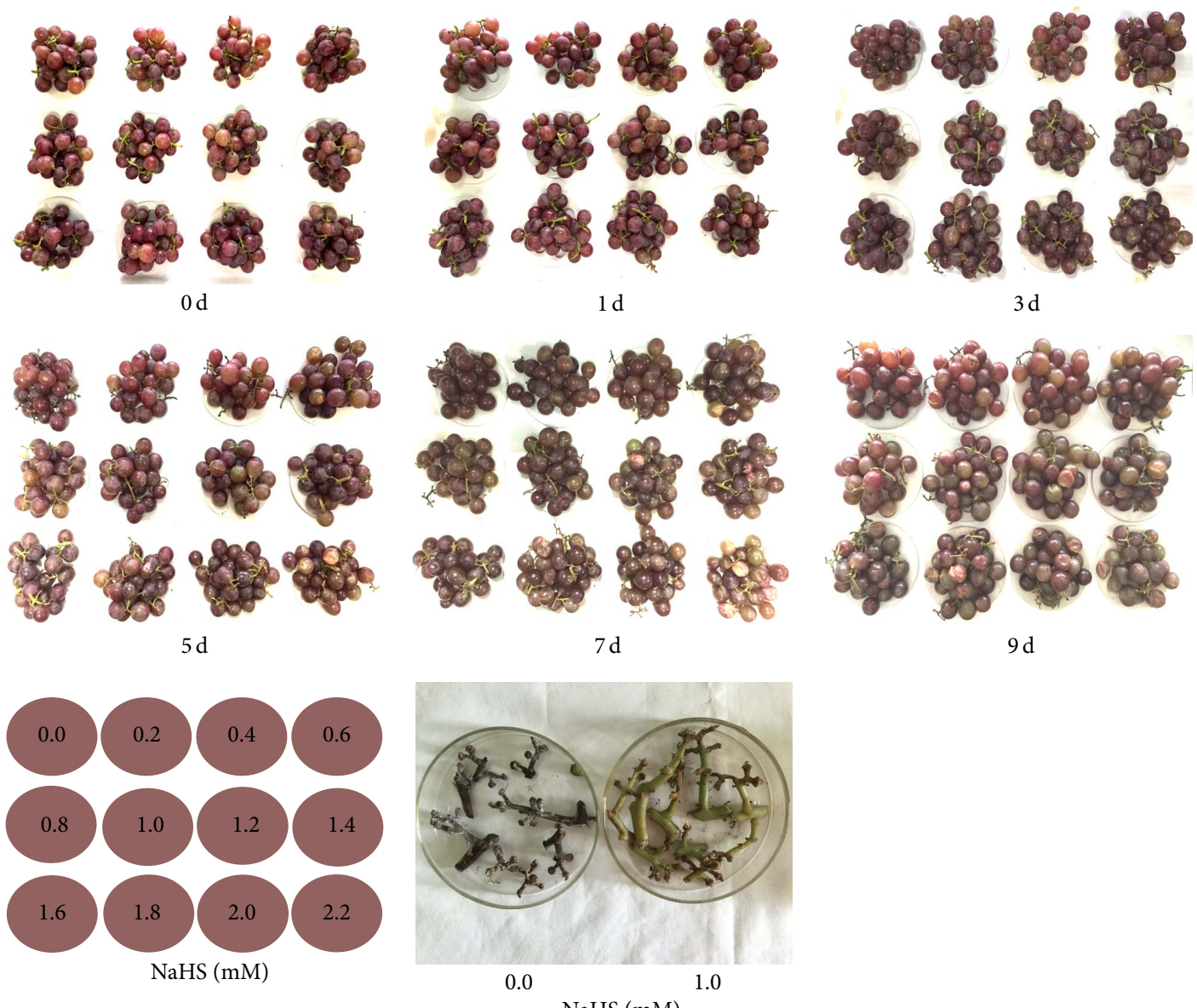

$1 \mathrm{~d}$

$3 \mathrm{~d}$

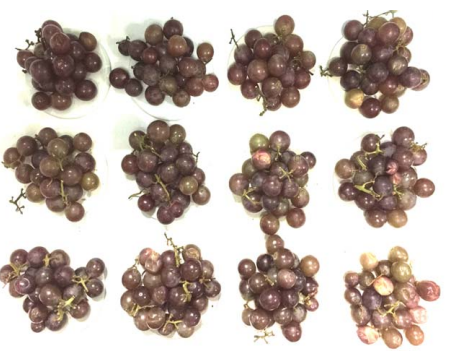

$7 \mathrm{~d}$

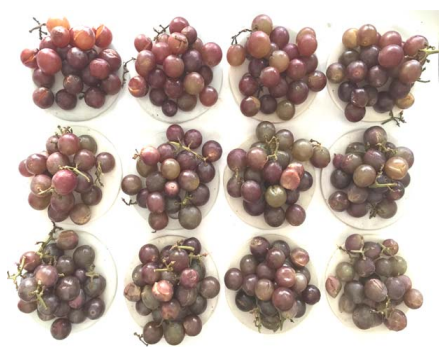

$9 \mathrm{~d}$

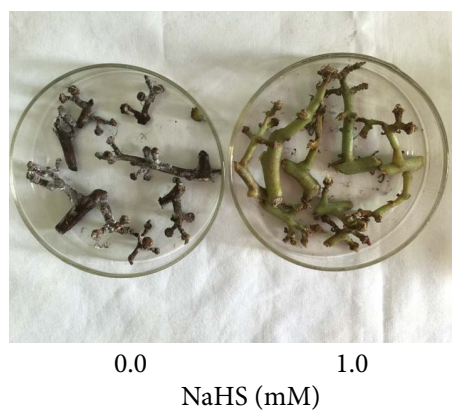

(a)

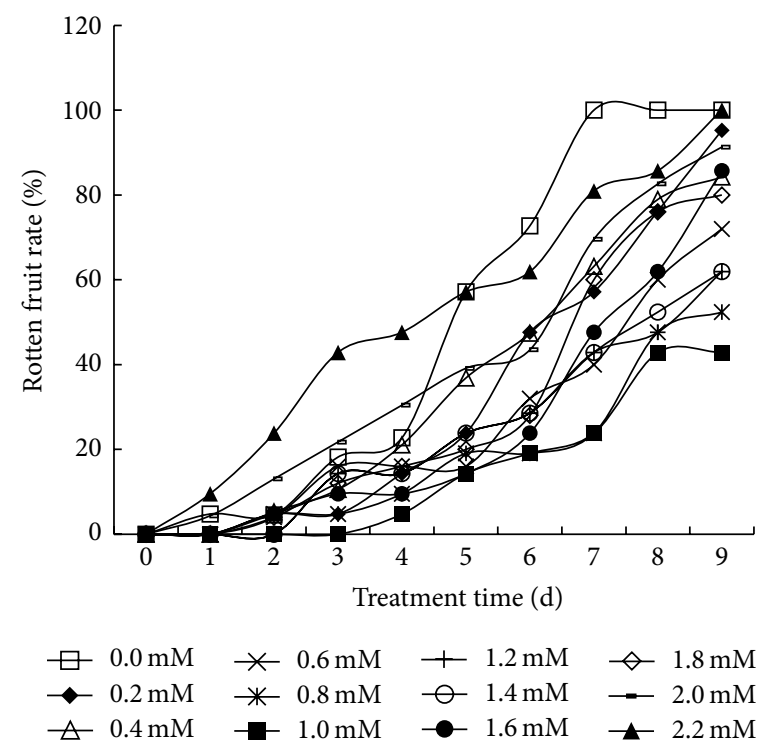

(b)

FIGURE 1: Hydrogen sulfide $\left(\mathrm{H}_{2} \mathrm{~S}\right)$ treatment delays the senescence and rotting of Kyoho grapes in a dose-dependent manner. Grape clusters were fumigated with $\mathrm{H}_{2} \mathrm{~S}$ released from different concentrations of aqueous $\mathrm{NaHS}(0,0.2,0.4,0.6,0.8,1.0,1.2,1.4,1.6,1.8,2.0$, and $2.2 \mathrm{mM})$ and the photographs of grapes were taken every two days (a). Grape rachis of control and $1.0 \mathrm{mM}$ NaHS treatment on day 5 of storage were presented in third panel of (a). Meanwhile, rotten fruit rates were recorded daily as shown in (b). The experiments and the following ones were carried out at $25^{\circ} \mathrm{C}$ and $85-90 \%$ relative humidity. 

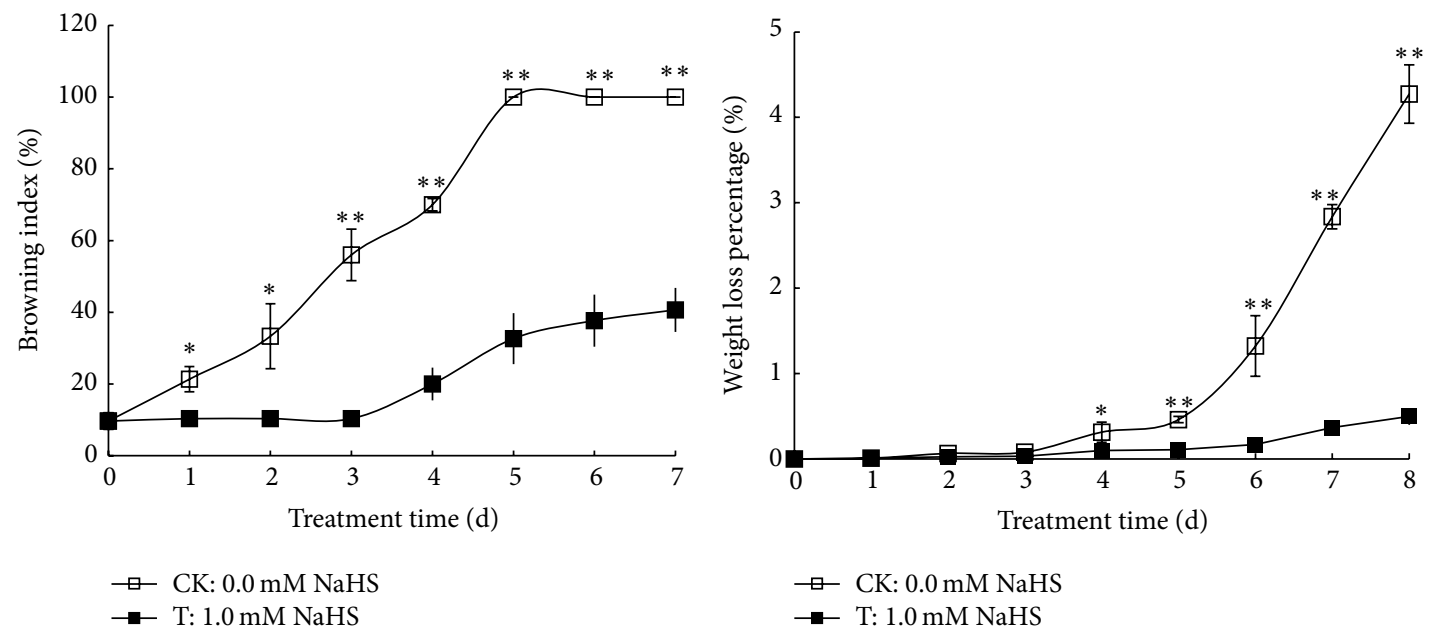

(a)

(b)
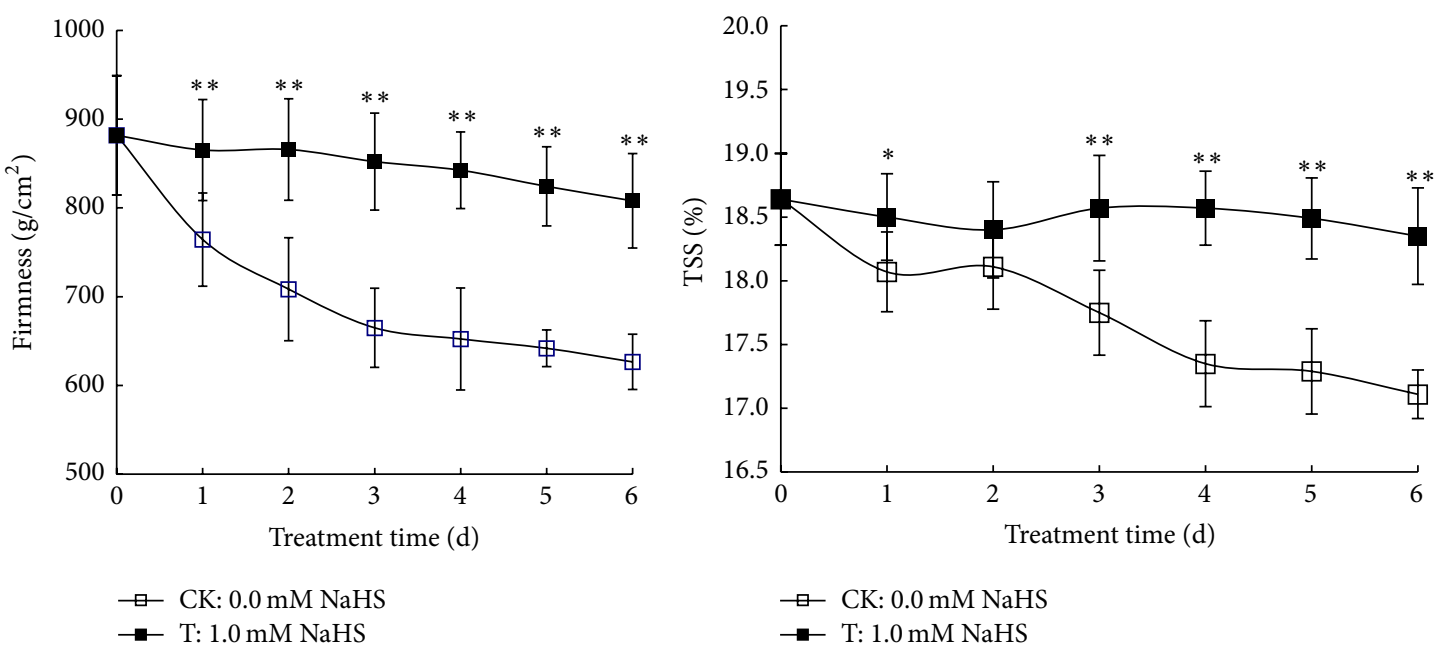

(c)

(d)

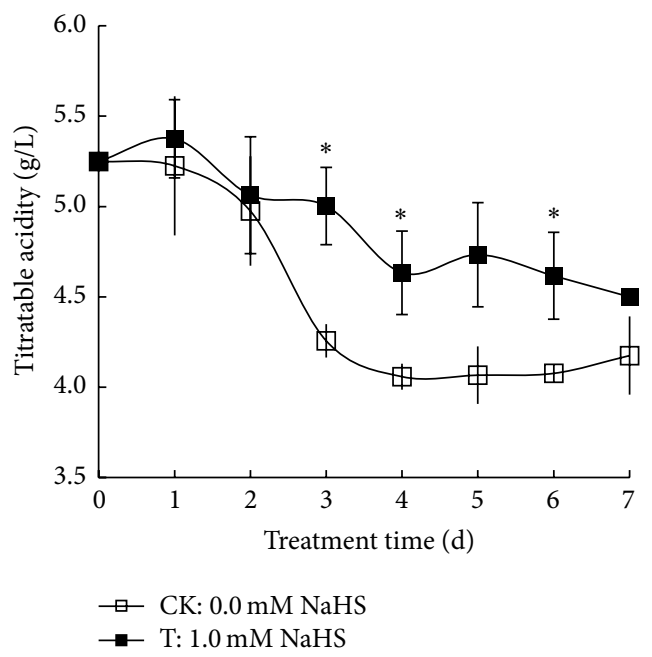

(e)

FiguRE 2: Effects of $\mathrm{H}_{2} \mathrm{~S}$ on browning index of grape rachis (a), weight loss percentage of grape berries (b), grape berry firmness (c), total soluble solids (TSS) (d), and titratable acidity (e) in grape flesh. Grape clusters were fumigated with $1.0 \mathrm{mM} \mathrm{H}_{2} \mathrm{~S}$ donor NaHS aqueous solution with water as the control groups for 0-8 d. Data are presented as means \pm SD (standard deviation) ( $n=3$ rachis for (a), $n=3$ grape clusters for (b), $n=8$ grape berries for (c), $n=10$ replicates for (d), and $n=3$ replicates for (e)). The symbols $*$ and $* *$ in this figure and the following ones stand for a significant difference between water control and $1.0 \mathrm{mM} \mathrm{NaHS}$ treatment at $P<0.05$ and $P<0.01$, respectively. FW $=$ fresh weight. 


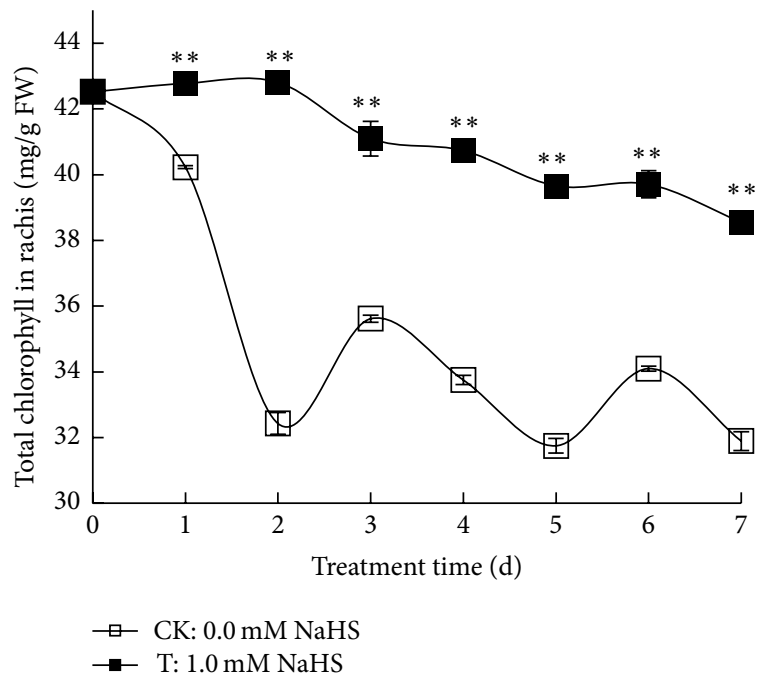

(a)

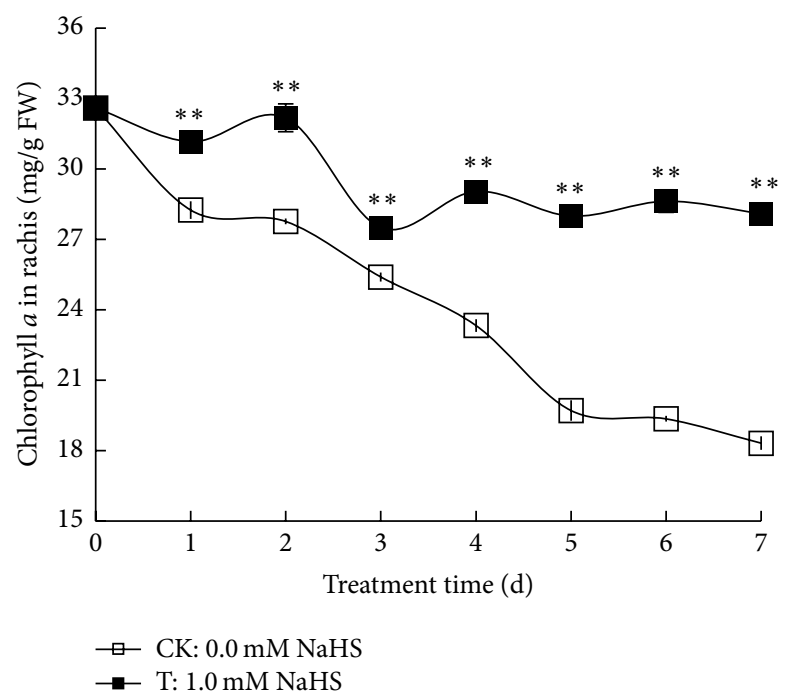

(b)
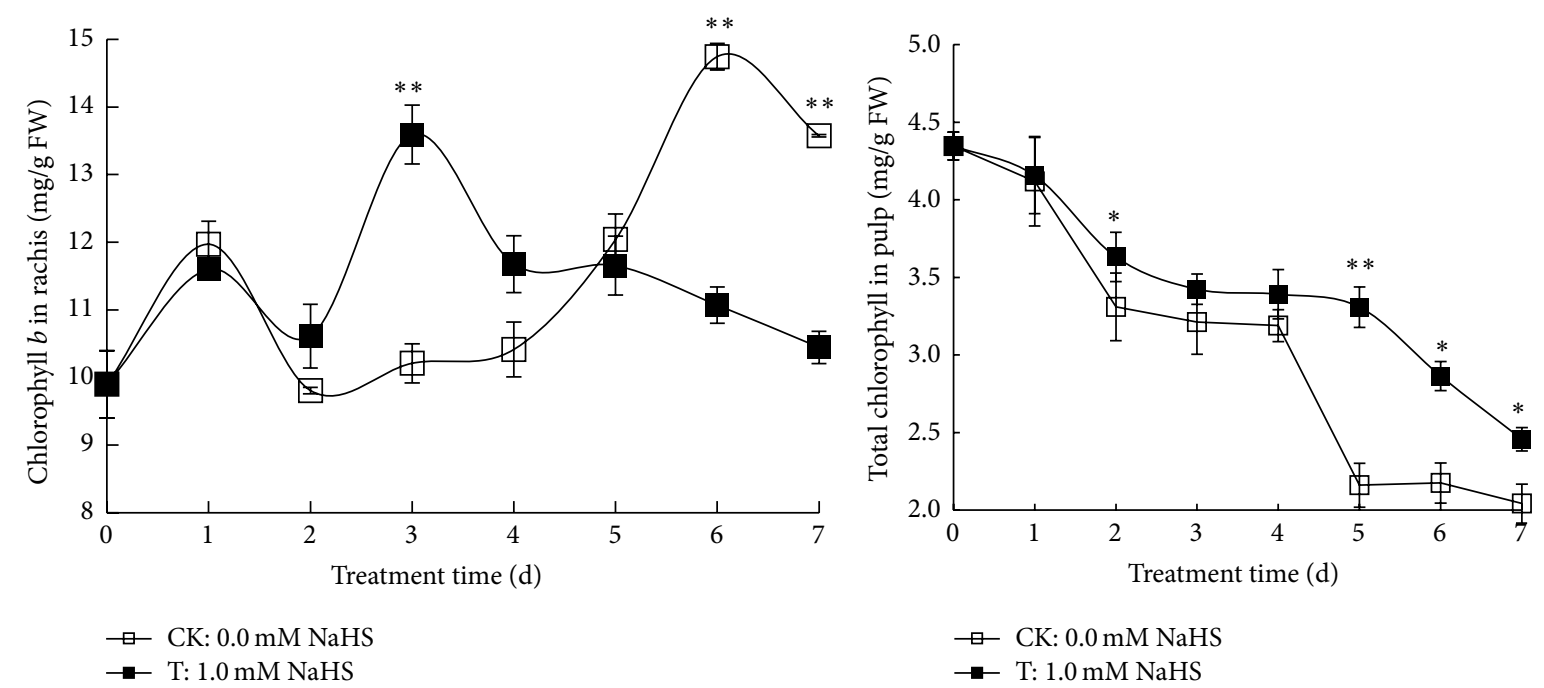

(c)



(e)

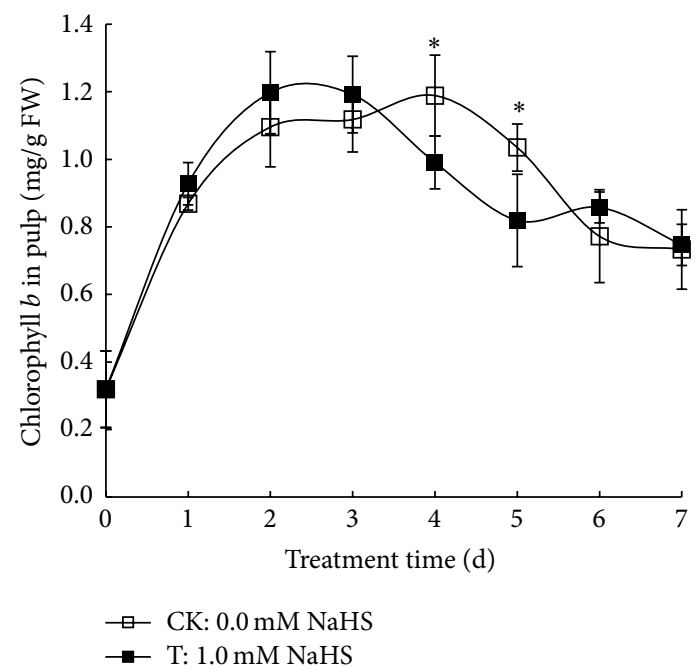

(f)

Figure 3: Continued. 


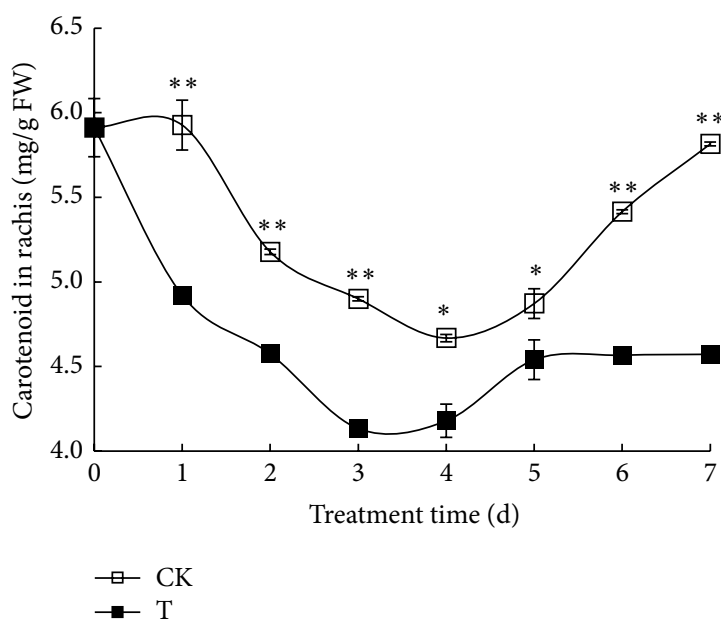

(g)

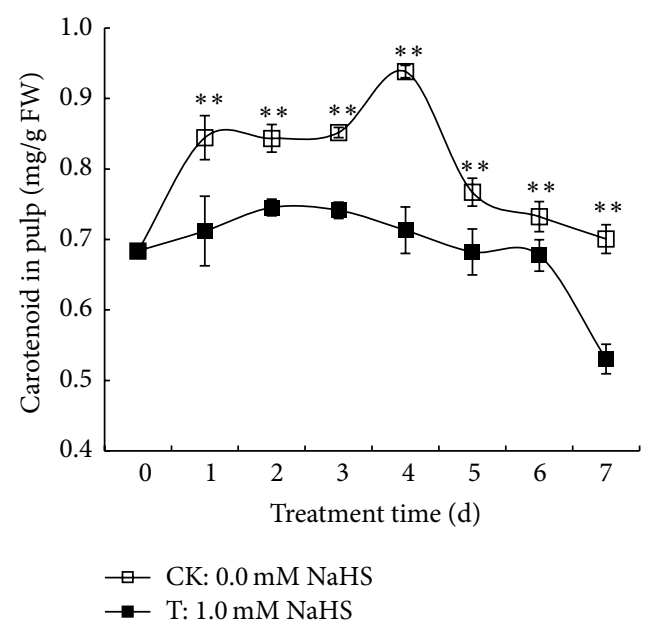

(h)

Figure 3: Effects of $\mathrm{H}_{2} \mathrm{~S}$ on the contents of total chlorophyll (a) and chlorophyll $a$ (b) and chlorophyll $b$ (c) in rachis and total chlorophyll (d) and chlorophyll $a(\mathrm{e})$ and chlorophyll $b$ (f) in grape pulp and on the content of carotenoid in rachis (g) and grape pulp (h). Grape clusters were fumigated with $1.0 \mathrm{mM} \mathrm{H}_{2} \mathrm{~S}$ donor NaHS aqueous solution with water as the control groups for $0-7 \mathrm{~d}$. Data are presented as means \pm $\mathrm{SD}(n=3$ for (a), (b), (c), and (g), $n=6$ for (d), (e), (f), and (h)). FW = fresh weight.

slower downward trend and was significantly higher than that of water control on days 3, 4, and 6 (Figure $2(\mathrm{e})$ ).

\subsection{Effect of $\mathrm{H}_{2} \mathrm{~S}$ on the Contents of Chlorophyll and} Carotenoid in Postharvest Grape Rachis and Pulp. Chlorophyll breakdown is shown to be associated with the first steps of the senescence process [33]. Besides, fruit ripening is often accompanied with the destruction of the green chlorophyll pigments and accumulation of yellow carotenoids in the flesh [34]. Thus, to understand how $\mathrm{H}_{2} \mathrm{~S}$ alleviated rachis browning and berry senescence, we determined the contents of chlorophyll and carotenoid in rachis and pulp. Chlorophyll contents (Figures 3(a) and 3(d)) were expressed as the sum of chlorophyll $a$ (Figures 3(b) and 3(e)) and chlorophyll $b$ (Figures 3(c) and 3(f)). In rachis, total chlorophyll content as well as the amounts of chlorophyll $a$ showed a decline trend during storage in both water controls and $\mathrm{H}_{2} \mathrm{~S}$ treatment, while $\mathrm{H}_{2} \mathrm{~S}$ fumigation maintained a relatively stable level of total chlorophyll and chlorophyll $a$ during the storage (Figures 3(a) and 3(b)). Similarly, a decrease in total chlorophyll content in pulp was also observed in water controls and $\mathrm{H}_{2} \mathrm{~S}$ treatment, whereas $\mathrm{H}_{2} \mathrm{~S}$ helped to maintain significantly higher level of total chlorophyll on days 2, 5, 6, and 7 compared with water control (Figure 3(d)). The content of chlorophyll $a$ in both control and $\mathrm{H}_{2} \mathrm{~S}$ treatment showed a decreasing trend along with time, while the content in $\mathrm{H}_{2} \mathrm{~S}$ treatment was significantly higher than that of control on days $2,4,5,6$, and 7 (Figure 3(e)). However, a slightly higher level of chlorophyll $b$ was found in control grape compared with $\mathrm{H}_{2} \mathrm{~S}$-treated ones on days 4 and 5 (Figure 3(f)).

Changes of carotenoid content in rachis and pulp are shown in Figures 3(g) and 3(h). During the whole storage period, carotenoid content in control group was always higher than that of $\mathrm{H}_{2} \mathrm{~S}$ treatment in both the rachis and pulp. In grape rachis, carotenoid content decreased and bottomed on day 4 for water control and day 3 for NaHS treatment followed by an increase (Figure 3(g)). Carotenoid content in grape pulp of water control increased steadily and peaked on day 4 followed by a decline, while only slight change was observed in $\mathrm{H}_{2} \mathrm{~S}$-treated berries except a drop on day 7 . The data of chlorophyll and carotenoid content suggested the role of $\mathrm{H}_{2} \mathrm{~S}$ in preventing chlorophyll breakdown and carotenoid accumulation in both grape rachis and pulp.

3.4. Effect of $\mathrm{H}_{2} \mathrm{~S}$ on the Contents of Ascorbic Acid, Flavonoid, Total Phenolics, Reducing Sugar, and Soluble Protein in Grape Pulp. Ascorbic acid, flavonoid, and phenols are natural antioxidants and important nutrient traits of fruit. As shown in Figure 4(a), the content of ascorbic acid decreased to a bottom on day 2 for control and on day 3 for $\mathrm{H}_{2} \mathrm{~S}$ treatment followed by a gradual increase. However, $\mathrm{H}_{2} \mathrm{~S}$ treatment sustained significantly higher content of ascorbic acid on days $1,2,6$, and 7 in comparison to water control. Figure 4(b) illustrated a decreasing trend of flavonoid content in grape berries treated with $\mathrm{H}_{2} \mathrm{~S}$ or not, whereas $\mathrm{H}_{2} \mathrm{~S}$ treatment sustained significantly higher level of flavonoid compared with water control. Similar decreasing trend was also observed in the changes of phenolics content (Figure 4(c)). However, in comparison to water control, $\mathrm{H}_{2} \mathrm{~S}$ fumigation significantly alleviated the decrease and maintained higher content of phenolics during the whole storage.

The contents of reducing sugar and soluble protein in grape berries are shown in Figures 4(d) and 4(e). Reducing sugar, as a primary energy substance, is a key energy source in postharvest fruit and vegetables. Reducing sugar in water control declined sharply and bottomed on day 4 followed by a surge till day 6 . However, there was only slight fluctuation of reducing sugar in $\mathrm{H}_{2} \mathrm{~S}$-treated berries and significantly higher level of reducing sugar was observed on days 2 to 5 relative to that of water control. Soluble protein content 


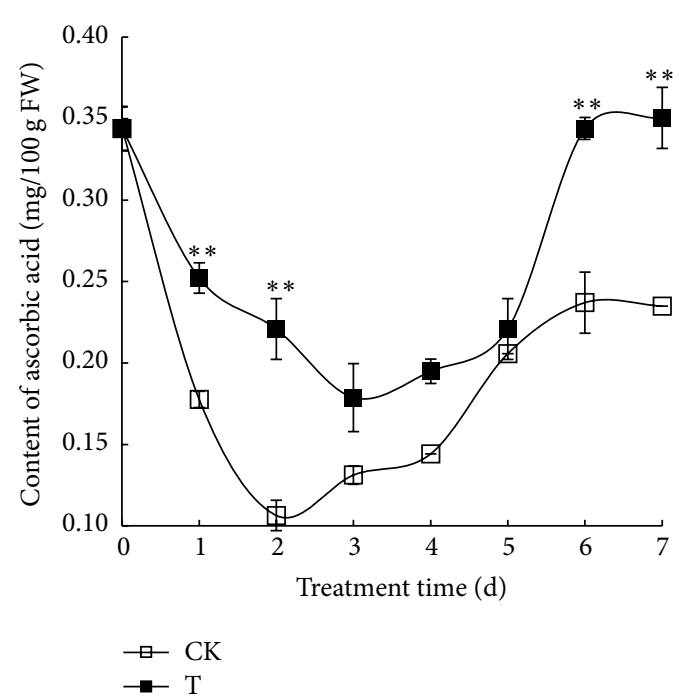

(a)

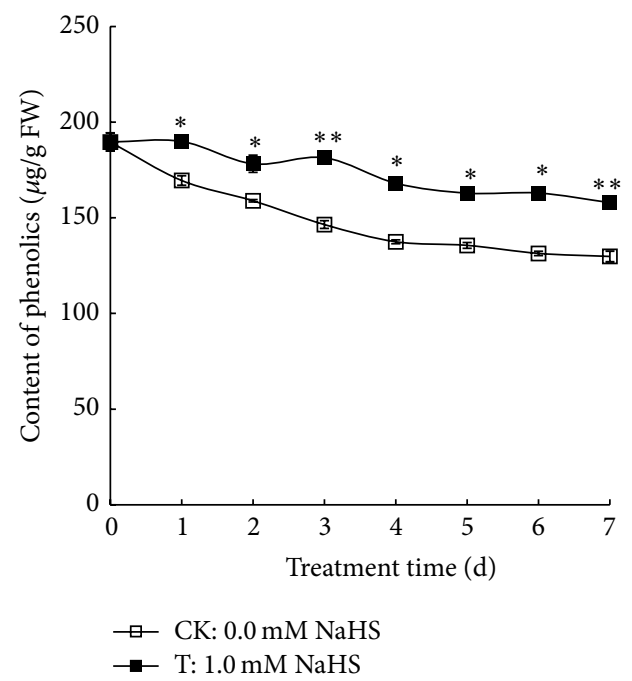

(c)

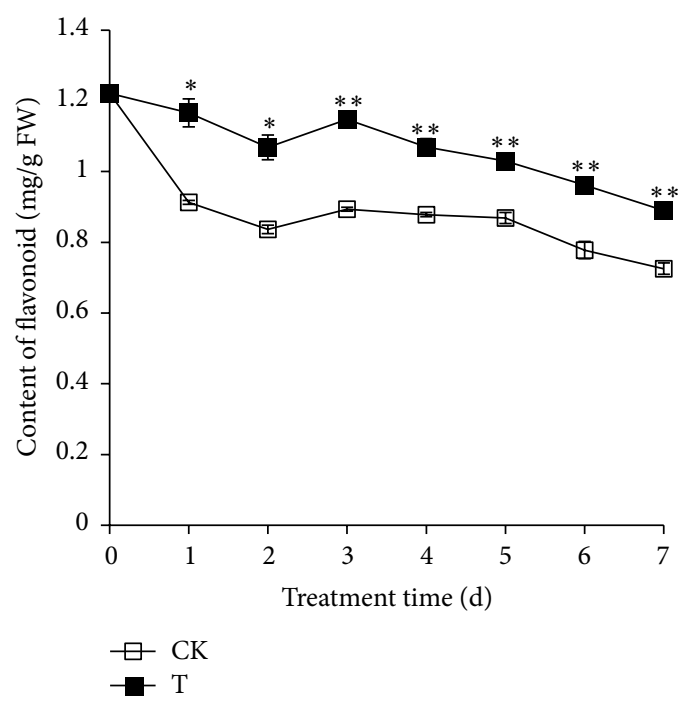

(b)

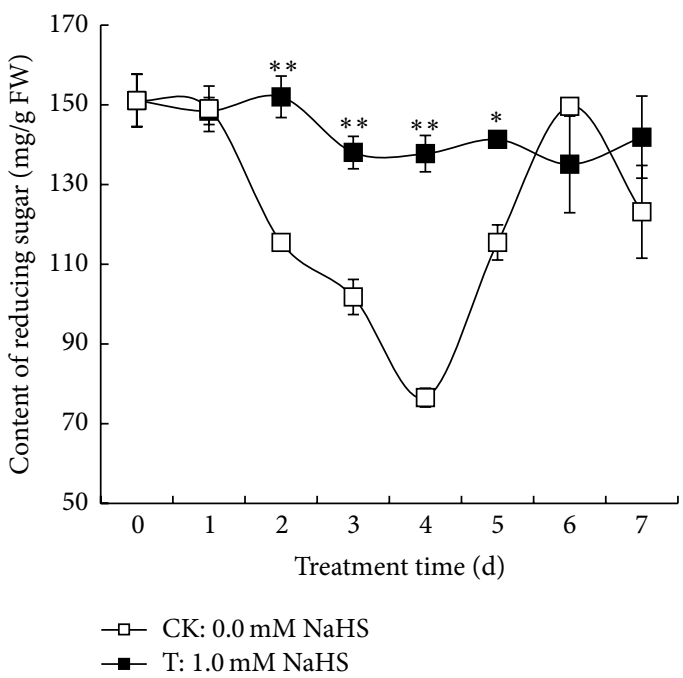

(d)

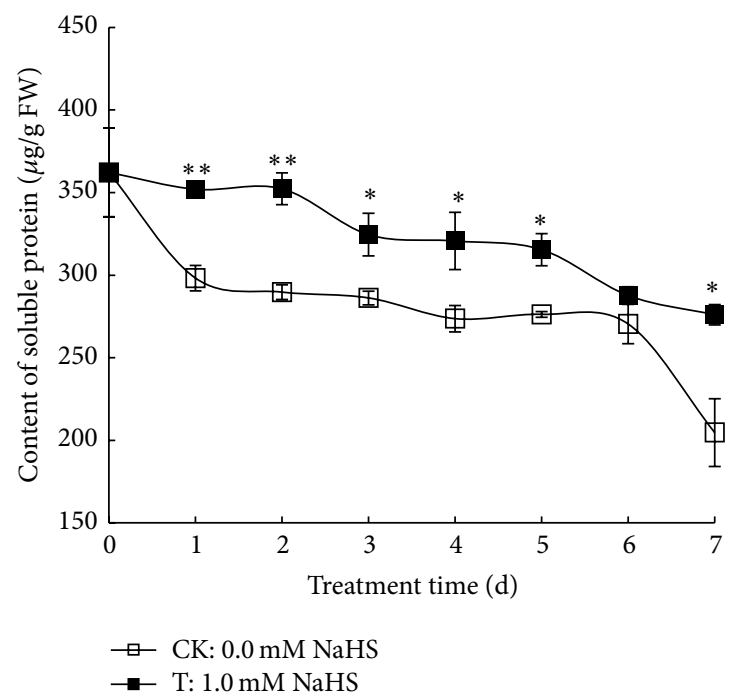

(e)

FIGURE 4: Effects of $\mathrm{H}_{2} \mathrm{~S}$ on the contents of ascorbic acid (a), flavonoid (b), total phenolics (c), reducing sugar (d), and soluble protein (e) in grape pulp. Grape clusters were fumigated with $1.0 \mathrm{mM} \mathrm{H}_{2} \mathrm{~S}$ donor NaHS aqueous solution with water as the control groups for 0-7 d. Data are presented as means $\pm \mathrm{SD}(n=3)$. FW $=$ fresh weight. 


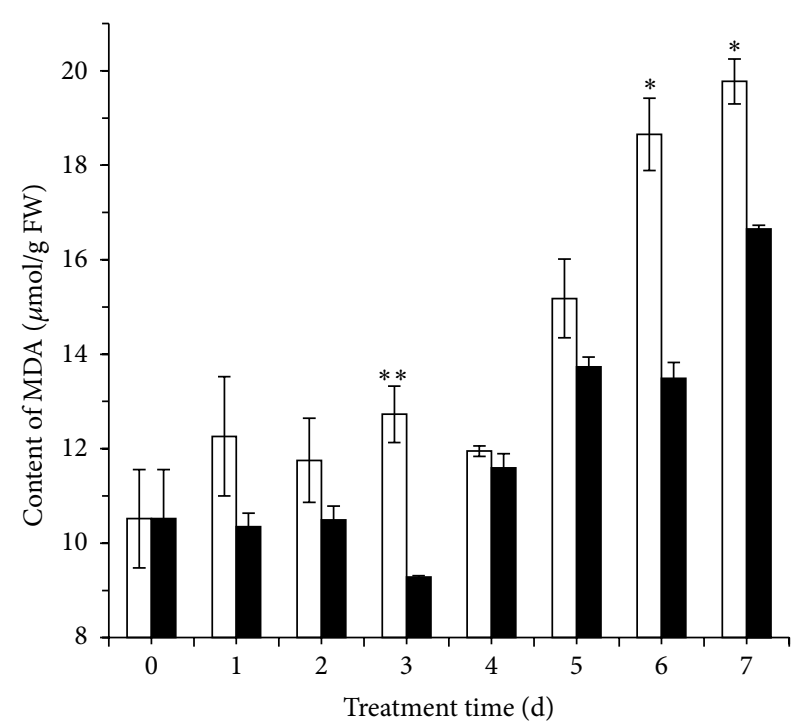

$0.0 \mathrm{mM} \mathrm{NaHS}$

- $1.0 \mathrm{mM} \mathrm{NaHS}$

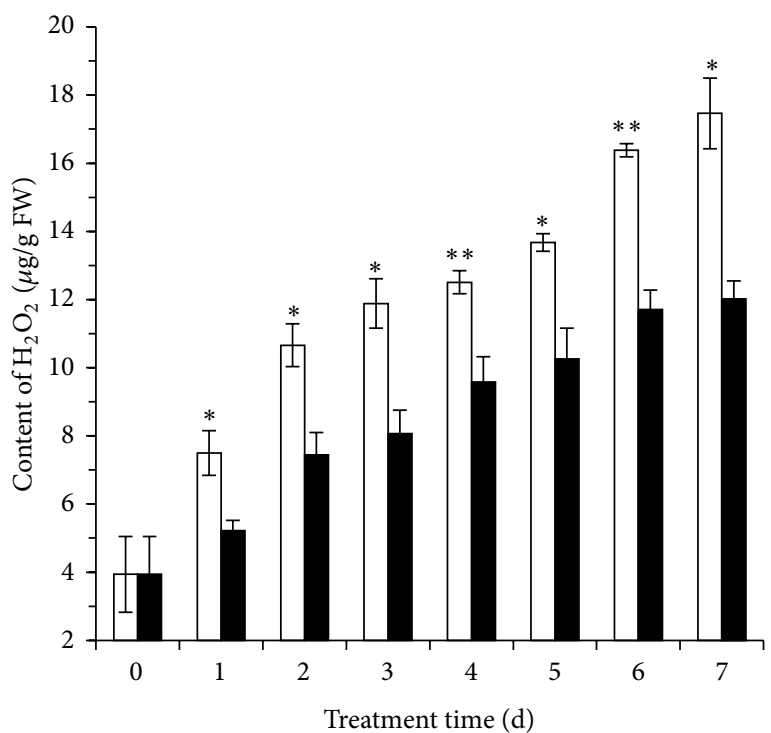

$\square 0.0 \mathrm{mM} \mathrm{NaHS}$

- $1.0 \mathrm{mM} \mathrm{NaHS}$

(a)

(b)

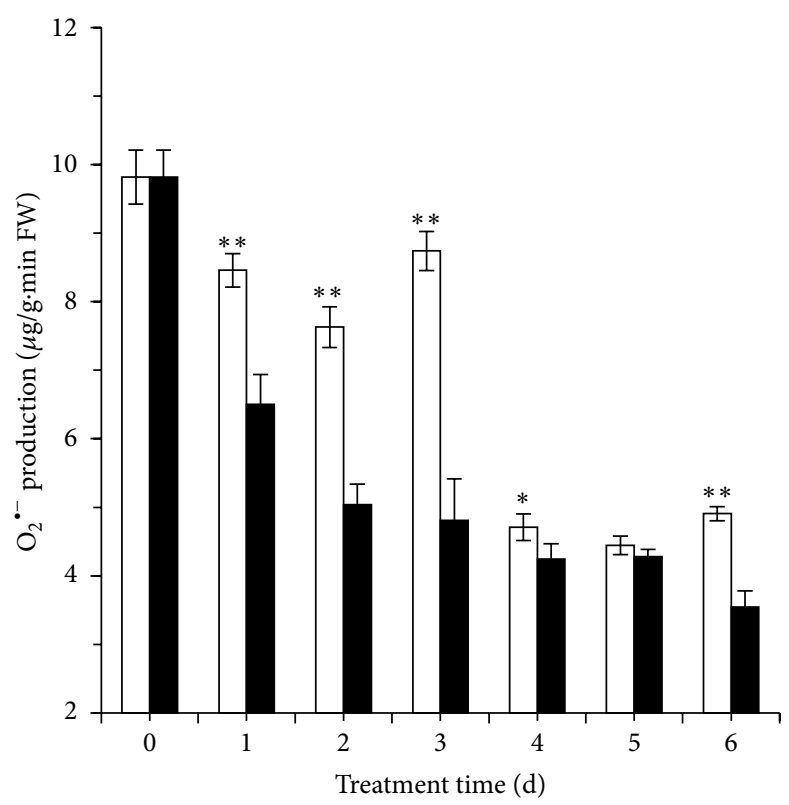

ㅁ $0.0 \mathrm{mM} \mathrm{NaHS}$

- $1.0 \mathrm{mM} \mathrm{NaHS}$

(c)

Figure 5: Effects of $\mathrm{H}_{2} \mathrm{~S}$ on the contents of malondialdehyde (MDA) (a), hydrogen peroxide $\left(\mathrm{H}_{2} \mathrm{O}_{2}\right)(\mathrm{b})$, and superoxide anion $\left(\mathrm{O}_{2}{ }^{--}\right)(\mathrm{c})$ production rate in grape pulp. Grape clusters were fumigated with $1.0 \mathrm{mM} \mathrm{H}_{2} \mathrm{~S}$ donor NaHS aqueous solution with water as the control groups for $0-7 \mathrm{~d}$. Data are presented as means $\pm \mathrm{SD}(n=3)$. FW $=$ fresh weight.

in both water control and $\mathrm{H}_{2} \mathrm{~S}$ decreased continually during the storage, but $\mathrm{H}_{2} \mathrm{~S}$ treatment significantly alleviated the decrease, suggesting the role of $\mathrm{H}_{2} \mathrm{~S}$ in preventing protein degradation.

3.5. Effect of $\mathrm{H}_{2} \mathrm{~S}$ on the Contents of $\mathrm{MDA}, \mathrm{H}_{2} \mathrm{O}_{2}$, and $\mathrm{O}_{2}{ }^{--}$ in Grape Pulp. The contents of MDA and $\mathrm{H}_{2} \mathrm{O}_{2}$ and the generation of $\mathrm{O}_{2}{ }^{--}$in grape fumigated with $\mathrm{H}_{2} \mathrm{~S}$ or water are shown in Figure 5. MDA is determined as an index of lipid peroxidation. As shown in Figure 5(a), MDA content in water control pulp fluctuated during the first four days of storage followed by a surge. An increase of MDA content was also observed in $\mathrm{H}_{2} \mathrm{~S}$-treated berries on day 4, but $\mathrm{H}_{2} \mathrm{~S}$ treatment significantly reduced MDA accumulation on days 3,6 , and 
7, implicating the role of $\mathrm{H}_{2} \mathrm{~S}$ in alleviating lipid peroxidation.

The overproduction of reactive oxygen species (ROS) is universally occurring during fruit senescence [21, 22]. Figure 5(b) shows that $\mathrm{H}_{2} \mathrm{O}_{2}$ content in grape pulp increased steadily in both $\mathrm{H}_{2} \mathrm{~S}$ treatment and water control, while $\mathrm{H}_{2} \mathrm{~S}$ treatment significantly reduced $\mathrm{H}_{2} \mathrm{O}_{2}$ accumulation. However, the content of $\mathrm{O}_{2}{ }^{--}$in control pulp fluctuated during the first 3 days of storage followed by a decrease on day 4. In contrast, the content of $\mathrm{O}_{2}{ }^{--}$in $\mathrm{H}_{2} \mathrm{~S}$ treatment declined continuously in pulp and was significantly lower compared to water control except on day 5.

3.6. Effect of $\mathrm{H}_{2} \mathrm{~S}$ on the Activities of APX, CAT, and LOX in Grape Peels and Pulp. To further understand the role of $\mathrm{H}_{2} \mathrm{~S}$ in ROS metabolism in grape, we determined the activities of enzymes involved in oxidative metabolism in plants, such as APX, CAT, and LOX. As showed in Figure 6(a), the activity of APX in grape peels of both control and $\mathrm{H}_{2} \mathrm{~S}$ treatment increased steadily and peaked on day 3 of storage followed by a gradual decline. However, APX activity in $\mathrm{H}_{2} \mathrm{~S}$-treated peels was significantly enhanced on days 1 to 3 compared with that of water control. The changes in APX activity in grape pulp are shown in Figure 6(b). APX activity in control peels increased during the first 2 days of storage and then fluctuated and peaked on day 4 followed by a drop on day 5 and then a plateau. Similar increase in APX activity was observed in $\mathrm{H}_{2} \mathrm{~S}$-treated peels till day 2 followed by a slight decrease till day 5 . However, $\mathrm{H}_{2} \mathrm{~S}$ treatment induced an about 3-fold increase in APX activity on day 6 in grape peels compared with control. As shown in Figure 6(c), $\mathrm{H}_{2} \mathrm{~S}$ treatment induced a swift increase of CAT activity on day 1 in grape peels followed by a gradual decrease till day 4 . Then, an increase was observed in CAT activity in peels treated with $\mathrm{H}_{2} \mathrm{~S}$ followed by a drop. Similar trend of the changes in CAT activity was seen in control peels, except that there was no activity increase on day 2 compared with that of $\mathrm{H}_{2} \mathrm{~S}$ treatment (Figure 6(c)). However, $\mathrm{H}_{2} \mathrm{~S}$ significantly promoted CAT activity in peels during the whole storage in comparison to water control except on day 7. Figure 6(d) illustrates the effect of $\mathrm{H}_{2} \mathrm{~S}$ on CAT activity in grape pulp. CAT activity in control pulp increased on day 1 followed by a slight decrease thereafter, whereas $\mathrm{H}_{2} \mathrm{~S}$ was found to induce an increase during the first two days of storage followed by a gradual increase. CAT activity in $\mathrm{H}_{2} \mathrm{~S}$-treated pulp was significantly higher than that of control on days 2 and 3 but was lower than that of control on days 6 and 7.

LOXs are enzymes that catalyze the hydroperoxidation of polyunsaturated fatty acids. As shown in Figure 6(e), LOX activity in control peels increased steadily and reached a maximum value on day 3 followed by a slight decline. Similar trend of changes of LOX activity was observed in $\mathrm{H}_{2} \mathrm{~S}$-treated peels, while $\mathrm{H}_{2} \mathrm{~S}$ significantly reduced LOX activity on days 2, 4,6 , and 7 compared with water control. Figure 6(f) showed that $\mathrm{H}_{2} \mathrm{~S}$ also attenuated LOX activity in pulp during the first 4 days of storage. LOX activity in control pulp rose significantly till day 3 followed by a drop on day 5 . However, an attenuated increase in LOX activity was observed in $\mathrm{H}_{2} \mathrm{~S}$ treated pulp during the first 4 days of storage (Figure 6(f)).

\section{Discussion}

Table grapes are highly perishable and their quality deteriorates quickly after harvest because of water loss and fungal spoilage especially in developing countries where cold chain transportation is not always available [1]. Besides, rachis browning also has a great impact on consumer preference. Here, we provide an alternative strategy other than $\mathrm{SO}_{2}$ fumigation to maintain the freshness of grape berries and green color of the rachis. Water loss is responsible for large and significant changes in the composition and metabolism of detached fruit, which induces changes in color and palatability and loss of nutritional quality $[35,36]$. We found that $\mathrm{H}_{2} \mathrm{~S}$ treatment effectively reduced weight loss in grape clusters and maintained higher berry firmness compared to water control (Figures 2(b) and 2(c)). Higher titratable acidity (TA) indicates a marked delay in process of maturation and ripening and loss of acidity can cause the fruits to taste insipid during storage. $\mathrm{H}_{2} \mathrm{~S}$ fumigation alleviated the decrease in TA during grape storage, further suggesting the role of $\mathrm{H}_{2} \mathrm{~S}$ in delaying fruit maturation and ripening (Figure 2(e)).

During fruit ripening and senescence, green chlorophyll pigments were decomposed and yellow carotenoids accumulated in the flesh $[33,34]$. In the present research, chlorophyll degradation was observed in both grape rachis and pulp, which was consistent with previous findings that during storage there was upregulation of chlorophyll breakdown-related genes in rachis [37]. However, $\mathrm{H}_{2} \mathrm{~S}$ significantly prevented chlorophyll degradation and carotenoid accumulation in both rachis and pulp, further confirming the antisenescence role of $\mathrm{H}_{2} \mathrm{~S}$ in plants (Figure 3 ). Although grapes are nonclimacteric, the effect of ethylene on ripening at veraison is well established [38]. Rachis browning was believed to be associated mainly with dehydration, but there is evidence showing that ethylene acts as a major factor in rachis browning [1, 39]. Recent study shows that 1-methylcyclopropane (1-MCP), which is a potent inhibitor of ethylene action, delays rachis browning in three table-grape varieties whereas ethylene tends to enhance it [39]. Besides, treatment with cytokinin or abscisic acid (ABA) improves rachis quality during storage, further suggesting the involvement of senescence during rachis browning because cytokinin and ABA are known to have antisenescent effect in plant $[40,41]$. Thus, our finding of the role of $\mathrm{H}_{2} \mathrm{~S}$ in alleviating grape senescence and rachis browning highlights the possibility that $\mathrm{H}_{2} \mathrm{~S}$ might act as an antagonist to counteract ethylene-induced fruit senescence.

Plant senescence is usually accompanied with the accumulation of ROS which can potentially cause oxidative damage to cellular components, including lipid, protein, and nucleic acid [42]. The metabolism of ROS is controlled by a series of antioxidant enzymes including CAT and APX. We found that $\mathrm{H}_{2} \mathrm{O}_{2}$ was accumulated in control grape pulp while $\mathrm{H}_{2} \mathrm{~S}$ effectively reduced $\mathrm{H}_{2} \mathrm{O}_{2}$ accumulation and $\mathrm{O}_{2}{ }^{\circ-}$ content (Figures 5(b) and 5(c)). APX and CAT are the two enzymes responsible for $\mathrm{H}_{2} \mathrm{O}_{2}$ breakdown. In the present study, $\mathrm{H}_{2} \mathrm{~S}$ treatment significantly enhanced the activities of APX and CAT in both grape peels and pulp during storage, which helped to scavenge excessive ROS and reduced 


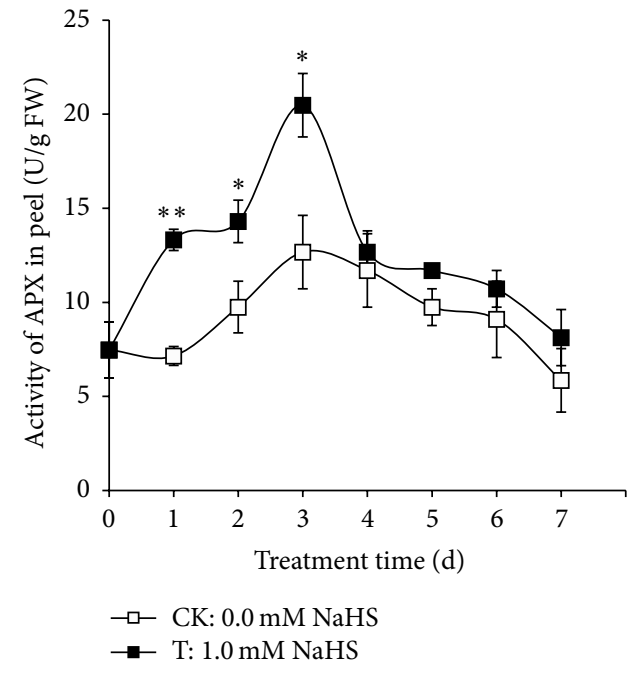

(a)

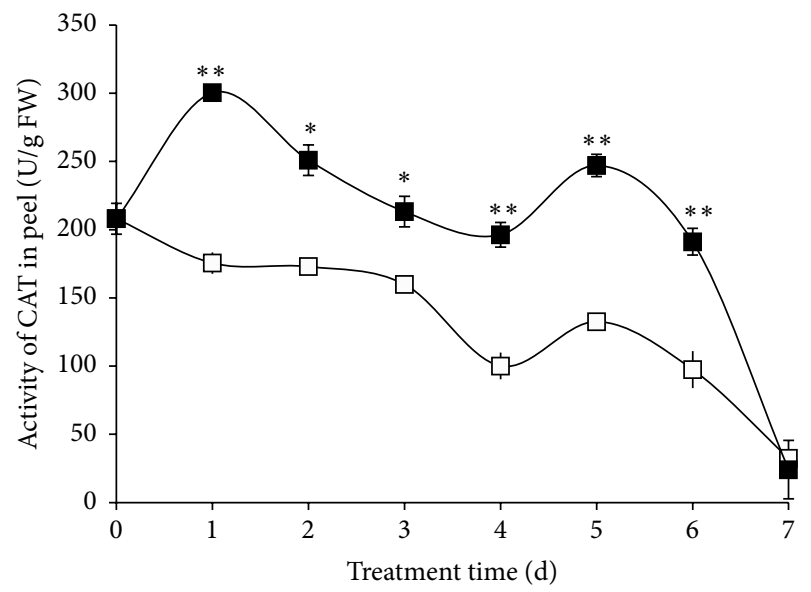

$\rightarrow-\mathrm{CK}: 0.0 \mathrm{mM} \mathrm{NaHS}$

$\rightarrow \mathrm{T}: 1.0 \mathrm{mM} \mathrm{NaHS}$

(c)

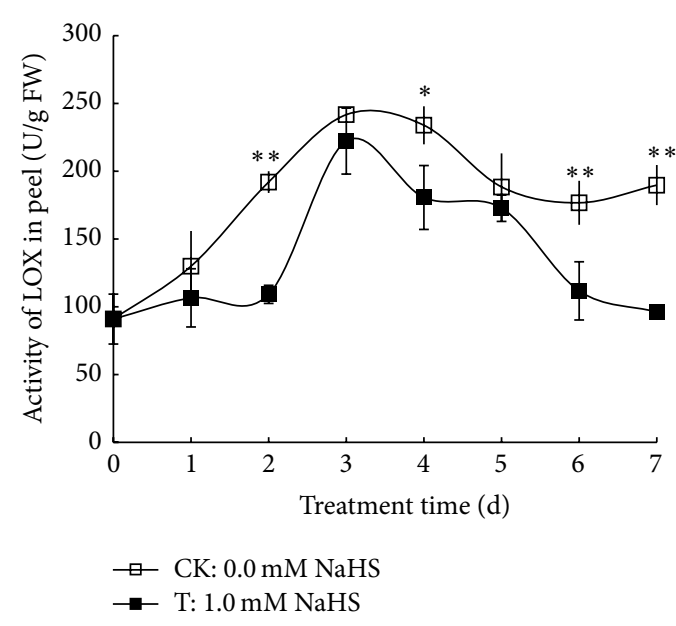

(e)

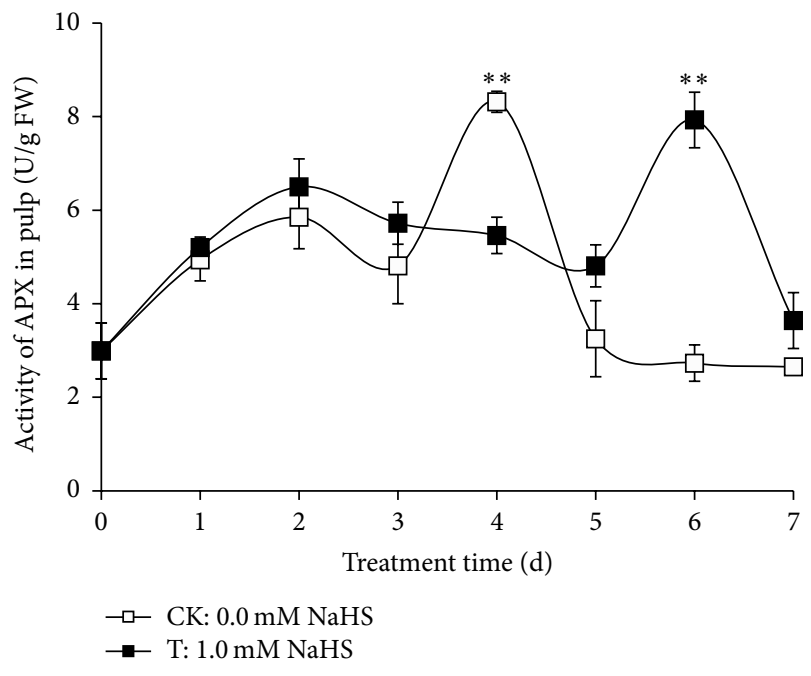

(b)

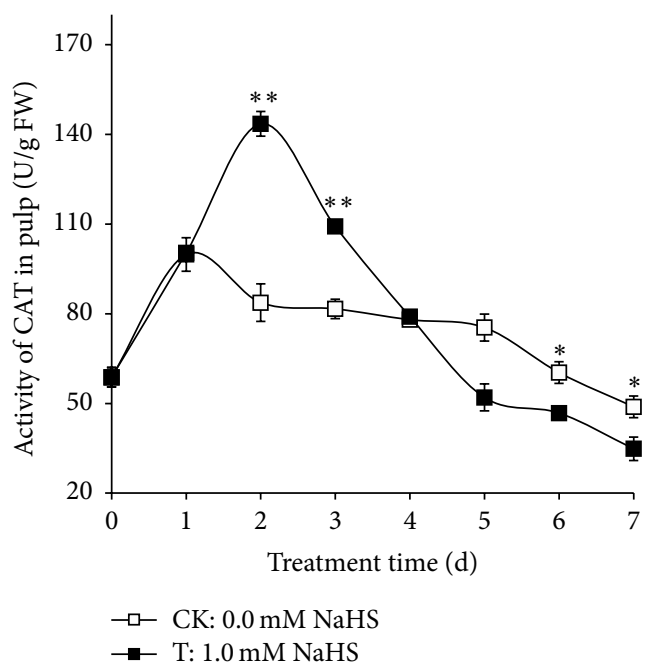

(d)

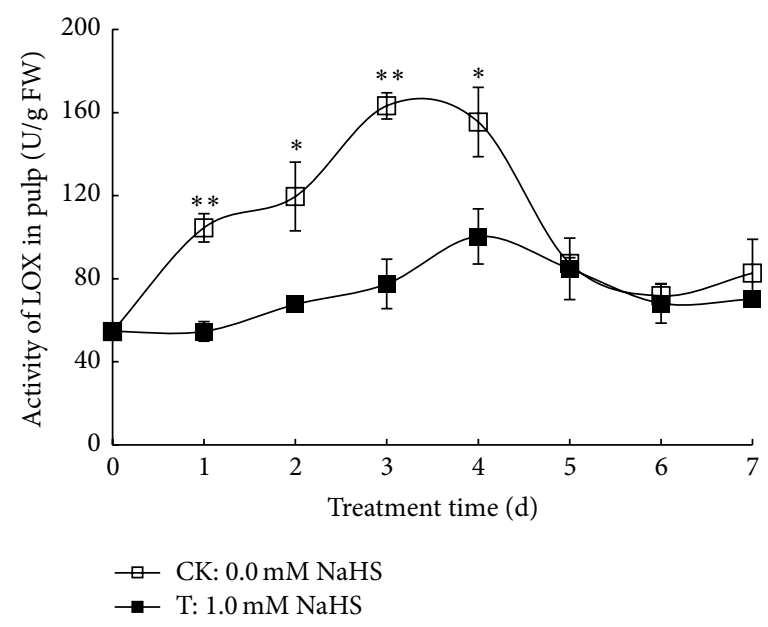

(f)

FIGURE 6: Effects of $\mathrm{H}_{2} \mathrm{~S}$ on the activities of ascorbate peroxidase (APX) in grape peels (a) and pulp (b), catalase (CAT) in peels (c) and pulp (d), and lipoxygenase (LOX) in peels (e) and pulp (f). Grape clusters were fumigated with $1.0 \mathrm{mM} \mathrm{H}_{2} \mathrm{~S}$ donor NaHS aqueous solution with water as the control groups for $0-7 \mathrm{~d}$. Data are presented as means $\pm \mathrm{SD}(n=3)$. FW $=$ fresh weight. 
ROS-caused damage to tissues (Figures 6(a), 6(b), 6(c), and $6(d))$. In addition to the antioxidative effect of antioxidant enzymes, nonenzymatic antioxidants or nutritional components such as ascorbic acid, flavonoid, and phenolics, which are important quality parameters used to evaluate the storage effect on table grapes, also help to maintain a balanced ROS metabolism by quenching ROS [43]. In the present research, $\mathrm{H}_{2} \mathrm{~S}$ was found to maintain higher levels of ascorbic acid, flavonoid, and phenolics in grape pulp compared with water control (Figures 4(a), 4(b), and 4(c)), highlighting the positive role of $\mathrm{H}_{2} \mathrm{~S}$ in grape storage. Other compounds such as chitosan-glucose complex, which has superior antioxidant activity in grape, were also found to delay the declines of ascorbic acid and titratable acidity and to induce antioxidant enzymes, thereby extending the postharvest life of grape [44]. Further, preharvest polyamines application which maintained higher value of antioxidant activity during grape storage also improved grape quality as indicated by the higher levels of phenolics and anthocyanins and alleviated weight loss and softening [45]. All the above publications highlighted the central role of oxidative stress during grape senescence and the effectiveness of antioxidant compounds (including $\mathrm{H}_{2} \mathrm{~S}$, polyamines, and chitosan-glucose complex) in delaying grape senescence.

LOX, as one of the key enzymes in membrane lipid peroxidation, is capable of catalyzing the peroxidation of unsaturated fatty acids to form a series of reactive oxygen species and thereby causing disorders in the normal physiological metabolic activity of cells [46]. We found that $\mathrm{H}_{2} \mathrm{~S}$ significantly inhibited the increase in LOX activity and meanwhile reduced the accumulation of MDA, which is a product of lipid peroxidation and a marker of oxidation of the plasma membrane [46] (Figures 5(a), 6(e), and 6(f)).

In all, our results indicated that $\mathrm{H}_{2} \mathrm{~S}$ could alleviate postharvest senescence of grape and maintain high fruit quality by decreasing ROS accumulation, improving antioxidant enzyme activities, and reducing lipid peroxidation, thereby maintaining the stability of the membrane structure.

\section{Conclusion}

In summary, we demonstrated that exogenous application of $\mathrm{H}_{2} \mathrm{~S}$ effectively alleviated postharvest senescence of grapes by preventing rachis browning and berry rotting and maintaining grape firmness, soluble solids, titratable acidity, and natural antioxidants during postharvest storage. The protective role of $\mathrm{H}_{2} \mathrm{~S}$ in grapes could be attributed to the increased activities of ROS-scavenging enzymes which bring about a repression on the production of ROS such as $\mathrm{H}_{2} \mathrm{O}_{2}$ and $\mathrm{O}_{2}{ }^{--}$and to the decreased level of LOX activity. In all, we provided strong evidence that $\mathrm{H}_{2} \mathrm{~S}$ effectively alleviated postharvest senescence and rotting of Kyoho grape by modulating antioxidant enzymes and attenuating lipid peroxidation. Considering the critical role of ethylene in postharvest senescence of grape berries and rachis, it will be interesting to know whether $\mathrm{H}_{2} \mathrm{~S}$ is antagonistically involved in ethylene pathway.

\section{Competing Interests}

The authors declare that there is no conflict of interests regarding the publication of this paper.

\section{Authors' Contributions}

Zhi-Jing Ni and Kang-Di Hu contributed equally to this work.

\section{Acknowledgments}

This work was supported by the Natural Science Foundation of China (nos. 31271803, 31301820, 31300133, and 31470013), the National Science and Technology Support Program (2013BAD09B03), the Scientific Research Foundation for Returned Overseas Chinese Scholars (SRF for ROCS, MOE), the Major Projects of Science and Technology in Anhui Province (15czz03115), the Natural Science Foundations of Anhui Province (11040606M85), and the Anhui Provincial Education Department (nos. 2012AJZR0028 and ZD200910).

\section{References}

[1] C. H. Crisosto, J. L. Smilanick, and N. K. Dokoozlian, “Table grapes suffer water loss, stem browning during cooling delays," California Agriculture, vol. 55, no. 1, pp. 39-42, 2001.

[2] A. Lichter, F. M. Gabler, and J. L. Smilanick, "Control of spoilage in table grapes," Stewart Postharvest Review, vol. 2, no. 6, pp. 1$10,2006$.

[3] L. F. Green, "Sulphur dioxide and food preservation-a review," Food Chemistry, vol. 1, no. 2, pp. 103-124, 1976.

[4] A. Lichter, Y. Zutahy, T. Kaplunov, Z. Shacham, N. Aharoni, and S. Lurie, "The benefits of modified atmosphere of ethanoltreated grapes," Acta Horticulturae, vol. 682, pp. 1739-1744, 2005.

[5] R. Wang, "Physiological implications of hydrogen sulfide: a whiff exploration that blossomed," Physiological Reviews, vol. 92, no. 2, pp. 791-896, 2012.

[6] L. G. Wilson, R. A. Bressan, and P. Filner, "Light-dependent emission of hydrogen sulfide from plants," Plant Physiology, vol. 61, no. 2, pp. 184-189, 1978.

[7] H. Rennenberg, "Role of $O$-acetylserine in hydrogen sulfide emission from pumpkin leaves in response to sulfate," Plant Physiology, vol. 73, no. 3, pp. 560-565, 1983.

[8] T. Rausch and A. Wachter, "Sulfur metabolism: a versatile platform for launching defence operations," Trends in Plant Science, vol. 10, no. 10, pp. 503-509, 2005.

[9] C. Álvarez, L. Calo, L. C. Romero, I. García, and C. Gotor, "An OAcetylserine(thiol)lyase homolog with 1-Cysteine desulfhydrase activity regulates cysteine homeostasis in arabidopsis," Plant Physiology, vol. 152, no. 2, pp. 656-669, 2010.

[10] D. Yarmolinsky, G. Brychkova, A. Kurmanbayeva et al., "Impairment in sulfite reductase leads to early leaf senescence in tomato plants," Plant Physiology, vol.165, no. 4, pp. 1505-1520, 2014.

[11] J. Chen, F.-H. Wu, W.-H. Wang et al., "Hydrogen sulphide enhances photosynthesis through promoting chloroplast biogenesis, photosynthetic enzyme expression, and thiol redox modification in Spinacia oleracea seedlings," Journal of Experimental Botany, vol. 62, no. 13, pp. 4481-4493, 2011. 
[12] C. García-Mata and L. Lamattina, "Hydrogen sulphide, a novel gasotransmitter involved in guard cell signalling," New Phytologist, vol. 188, no. 4, pp. 977-984, 2010.

[13] H. Zhang, L.-Y. Hu, K.-D. Hu, Y.-D. He, S.-H. Wang, and J.P. Luo, "Hydrogen sulfide promotes wheat seed germination and alleviates oxidative damage against copper stress," Journal of Integrative Plant Biology, vol. 50, no. 12, pp. 1518-1529, 2008.

[14] H. Zhang, S.-L. Hu, Z.-J. Zhang et al., "Hydrogen sulfide acts as a regulator of flower senescence in plants," Postharvest Biology and Technology, vol. 60, no. 3, pp. 251-257, 2011.

[15] H. Zhang, J. Tang, X.-P. Liu et al., "Hydrogen sulfide promotes root organogenesis in Ipomoea batatas, Salix matsudana and Glycine max," Journal of Integrative Plant Biology, vol. 51, no. 12, pp. 1086-1094, 2009.

[16] Z. P. Jin, J. J. Shen, Z. J. Qiao, G. D. Yang, R. Wang, and Y. X. Pei, "Hydrogen sulfide improves drought resistance in Arabidopsis thaliana," Biochemical and Biophysical Research Communications, vol. 414, no. 3, pp. 481-486, 2011.

[17] Z. P. Jin, S. W. Xue, Y. N. Luo et al., "Hydrogen sulfide interacting with abscisic acid in stomatal regulation responses to drought stress in Arabidopsis," Plant Physiology and Biochemistry, vol. 62, pp. 41-46, 2013.

[18] S. Raseetha, S. Y. Leong, D. J. Burritt, and I. Oey, "Understanding the degradation of ascorbic acid and glutathione in relation to the levels of oxidative stress biomarkers in broccoli (Brassica oleracea L. italica cv. Bellstar) during storage and mechanical processing," Food Chemistry, vol. 138, no. 2-3, pp. 1360-1369, 2013.

[19] H. Hu, W. Shen, and P. Li, "Effects of hydrogen sulphide on quality and antioxidant capacity of mulberry fruit," International Journal of Food Science and Technology, vol. 49, no. 2, pp. 399409, 2014.

[20] S.-P. Gao, K.-D. Hu, L.-Y. Hu et al., "Hydrogen sulfide delays postharvest senescence and plays an antioxidative role in freshcut kiwifruit," HortScience, vol. 48, no. 11, pp. 1385-1392, 2013.

[21] S.-P. Li, K.-D. Hu, L.-Y. Hu et al., "Hydrogen sulfide alleviates postharvest senescence of broccoli by modulating antioxidant defense and senescence-related gene expression," Journal of Agricultural and Food Chemistry, vol. 62, no. 5, pp. 1119-1129, 2014.

[22] L.-Y. Hu, S.-L. Hu, J. Wu et al., "Hydrogen sulfide prolongs postharvest shelf life of strawberry and plays an antioxidative role in fruits," Journal of Agricultural and Food Chemistry, vol. 60, no. 35, pp. 8684-8693, 2012.

[23] W. Jiang, Q. Sheng, Y. Jiang, and X. Zhou, "Effects of 1methylcyclopropene and gibberellic acid on ripening of Chinese jujube (Zizyphus jujuba M) in relation to quality," Journal of the Science of Food and Agriculture, vol. 84, no. 1, pp. 31-35, 2004.

[24] R. Porat, D. Pavoncello, J. Peretz, S. Ben-Yehoshua, and S. Lurie, "Effects of various heat treatments on the induction of cold tolerance and on the postharvest qualities of 'Star Ruby' grapefruit," Postharvest Biology and Technology, vol. 18, no. 2, pp. 159-165, 2000.

[25] H. K. Lichtenthaler and A. R. Wellburn, "Determinations of total carotenoids and chlorophylls a and b of leaf extracts in different solvents," Biochemical Society Transactions, vol. 11, no. 5, pp. 591-592, 1983.

[26] A. Nath, B. Bagchi, L. K. Misra, and B. C. Deka, "Changes in post-harvest phytochemical qualities of broccoli florets during ambient and refrigerated storage," Food Chemistry, vol. 127, no. 4, pp. 1510-1514, 2011.
[27] A. Pirie and M. G. Mullins, "Changes in anthocyanin and phenolics content of grapevine leaf and fruit tissues treated with sucrose, nitrate, and abscisic acid," Plant Physiology, vol. 58, no. 4, pp. 468-472, 1976.

[28] J. Zhishen, T. Mengcheng, and W. Jianming, “The determination of flavonoid contents in mulberry and their scavenging effects on superoxide radicals," Food Chemistry, vol. 64, no. 4, pp. 555$559,1999$.

[29] M. M. Bradford, "A rapid and sensitive method for the quantitation of microgram quantities of protein utilizing the principle of protein-dye binding," Analytical Biochemistry, vol. 72, no. 1-2, pp. 248-254, 1976.

[30] G. L. Miller, "Use of dinitrosalicylic acid reagent for determination of reducing sugar," Analytical Chemistry, vol. 31, no. 3, pp. 426-428, 1959.

[31] C. García-Limones, A. Hervás, J. A. Navas-Cortés, R. M. Jiménez-Díaz, and M. Tena, "Induction of an antioxidant enzyme system and other oxidative stress markers associated with compatible and incompatible interactions between chickpea (Cicer arietinum L.) and Fusarium oxysporum f. sp. ciceris," Physiological and Molecular Plant Pathology, vol. 61, no. 6, pp. 325-337, 2002.

[32] K. Surrey, "Spectrophotometric Method for Determination of Lipoxidase Activity," Plant Physiology, vol. 39, no. 1, pp. 65-70, 1964.

[33] S. Hörtensteiner, "Chlorophyll degradation during senescence," Annual Review of Plant Biology, vol. 57, pp. 55-77, 2006.

[34] J. Severo, A. Tiecher, J. Pirrello et al., "UV-C radiation modifies the ripening and accumulation of ethylene response factor (ERF) transcripts in tomato fruit," Postharvest Biology and Technology, vol. 102, pp. 9-16, 2015.

[35] R. Wills, B. McGlasson, D. Graham, and D. Joyce, Eds., Postharvest, CABI, Wallingford, UK, 5th edition, 2007.

[36] S. J. Kays and R. E. Paull, Eds., Postharvest Biology, Exon Press, Athens, Ga, USA, 2004.

[37] I. Balic, A. Moreno, D. Sanhueza et al., "Molecular and physiological study of postharvest rachis browning of table grape cV Red Globe," Postharvest Biology and Technology, vol. 72, pp. 4756, 2012.

[38] C. Chervin, A. El-Kereamy, J.-P. Roustan, A. Latché, J. Lamon, and M. Bouzayen, "Ethylene seems required for the berry development and ripening in grape, a non-climacteric fruit," Plant Science, vol. 167, no. 6, pp. 1301-1305, 2004.

[39] L. Li, T. Kaplunov, Y. Zutahy, A. Daus, R. Porat, and A. Lichter, "The effects of 1-methylcyclopropane and ethylene on postharvest rachis browning in table grapes," Postharvest Biology and Technology, vol. 107, pp. 16-22, 2015.

[40] C. M. Cantín, M. W. Fidelibus, and C. H. Crisosto, "Application of abscisic acid (ABA) at veraison advanced red color development and maintained postharvest quality of 'Crimson Seedless' grapes," Postharvest Biology and Technology, vol. 46, no. 3, pp. 237-241, 2007.

[41] E. Carvajal-Millán, T. Carvallo, J. A. Orozco et al., "Polyphenol oxidase activity, color changes, and dehydration in table grape rachis during development and storage as affected by $N$-(2chloro-4-pyridyl)-N-phenylurea," Journal of Agricultural and Food Chemistry, vol. 49, no. 2, pp. 946-951, 2001.

[42] G. Noctor and C. H. Foyer, "Ascorbate and glutathione: keeping active oxygen under control," Annual Review of Plant Physiology and Plant Molecular Biology, vol. 49, pp. 249-279, 1998. 
[43] K. Apel and H. Hirt, "Reactive oxygen species: metabolism, oxidative stress, and signal transduction," Annual Review of Plant Biology, vol. 55, pp. 373-399, 2004.

[44] P. Gao, Z. Zhu, and P. Zhang, "Effects of chitosan-glucose complex coating on postharvest quality and shelf life of table grapes," Carbohydrate Polymers, vol. 95, no. 1, pp. 371-378, 2013.

[45] S. H. Mirdehghan and S. Rahimi, "Pre-harvest application of polyamines enhances antioxidants and table grape (Vitis vinifera L.) quality during postharvest period," Food Chemistry, vol. 196, pp. 1040-1047, 2016.

[46] Y. Xing, X. Li, Q. Xu, J. Yun, Y. Lu, and Y. Tang, "Effects of chitosan coating enriched with cinnamon oil on qualitative properties of sweet pepper (Capsicum annuum L.)," Food Chemistry, vol. 124, no. 4, pp. 1443-1450, 2011. 


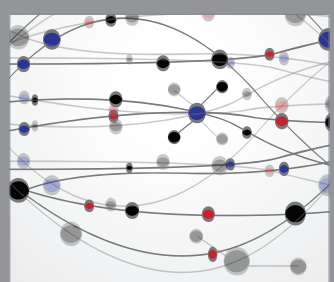

The Scientific World Journal
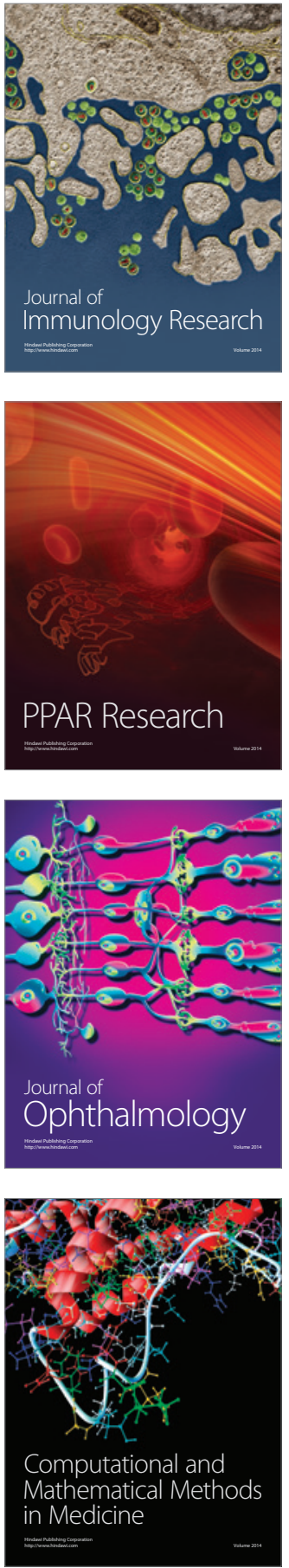

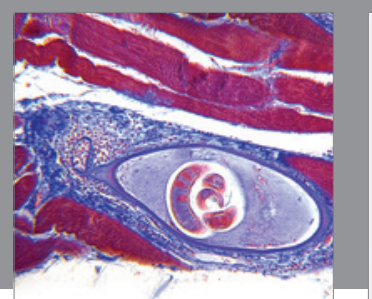

Gastroenterology Research and Practice

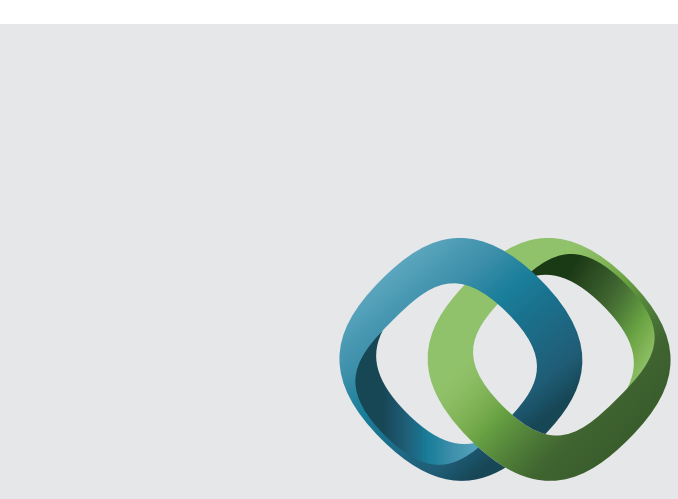

\section{Hindawi}

Submit your manuscripts at

http://www.hindawi.com
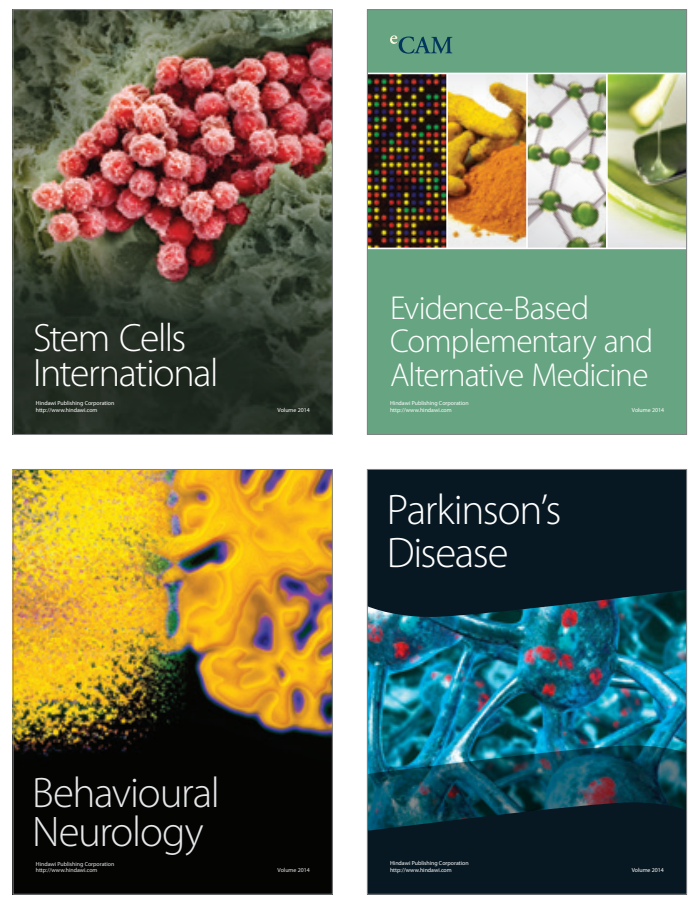
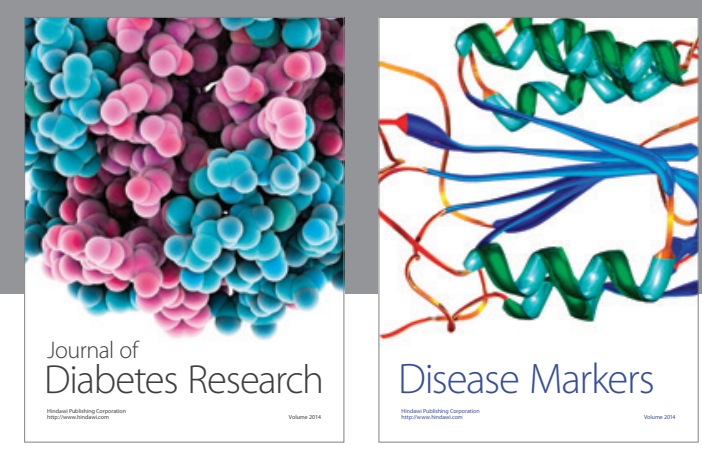

Disease Markers
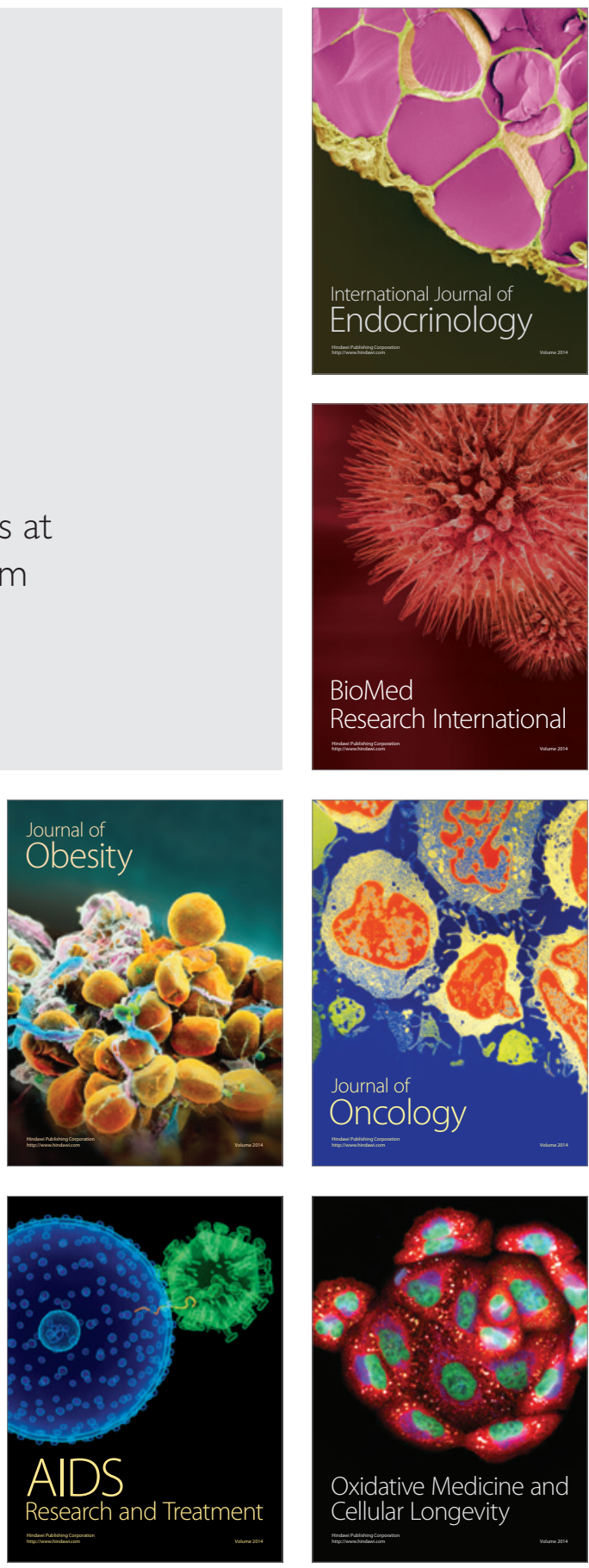